\title{
Balancing Digital-By-Default with Inclusion: A Study of the Factors Influencing E-Inclusion in the UK
}

\author{
Ahlam Al-Muwil $^{1} \cdot$ Vishanth Weerakkody $^{2} \cdot$ Ramzi El-haddadeh $^{3} \cdot$ Yogesh Dwivedi $^{4}$
}

Published online: 18 May 2019

(C) The Author(s) 2019

\begin{abstract}
Digital inclusion research has been critically important in drawing an understanding of how policies, society, organisations, and information technologies can all come together within a national environment that aspires to be a digital nation. This research aims to examine the factors influencing e-Inclusion in the UK within a digital-by-default policy for government services. This study is pursued through combining the Decomposed Theory of Planned Behaviour (DTPB) with Use and Gratification Theory (U\&G) and conducting a self-administered survey targeting 510 Internet users to study the level of citizens engagement with egovernment services in the UK. By incorporating gratification, trust, risk and external factors (i.e. self-efficacy, accessibility, availability, affordability) within DTPB, the proposed model of e-Inclusion used in the paper demonstrates a considerable explanatory and predictive power and offers a frame of reference to study the acceptance and usage of e-government within a national context where nearly all government transactions are digital-by-default. The findings revealed six dimensions as key inhibitors for e-Inclusion, namely: demographic, economic, social, cultural, political, and infrastructural.
\end{abstract}

Keywords E-inclusion $\cdot$ E-government $\cdot$ Digital-by-default $\cdot$ Government services $\cdot$ UK

\section{Introduction}

In social sciences, inclusion refers to a process, de facto and/or de jure, of including people in a given social structure, most often, in society at large. Conversely, social exclusion describes "The inability of our society to keep all groups and individuals within reach of what we expect as a society .... [or] to realize their full potential" (Power and Wilson 2000, p.1). in this context, e-Inclusion is broadly defined as social

Ahlam Al-Muwil

ahlam.al-muwil@brunel.ac.uk

$\triangle$ Vishanth Weerakkody

V.Weerakkody@bradford.ac.uk

Ramzi El-haddadeh

rhaddadeh@qu.edu.qa

Yogesh Dwivedi

y.k.dwivedi@swansea.ac.uk

1 Business School, Brunel University London, London, UK

2 School of Management, University of Bradford, Bradford, UK

3 College of Business and Economics, Qatar University, Doha, Qatar

4 School of Management, Swansea University, Swansea, UK inclusion in a knowledge society (Yu et al. 2018; Kaplan 2005) and in Europe, it remains one of the three strategic pillars of the i2010 inclusion strategic plan, which specifies primary goals of growth, employment, and quality of life (Helbig et al. 2009). The European strategy is to ensure that the benefits of the information society can be enjoyed by everyone, including people who are disadvantaged due to limited resources or education, age, gender, ethnicity and by people with disabilities as well as those living in less favoured areas. According to Wright and Wadhwa (2010) the term e-Inclusion has its roots in European Commission documents published in 1999 in which it is stated that, the objective of e-Inclusion is to bring every citizen, every school, and every company in Europe online.

Policies of e-inclusion in the UK have followed the European agenda. Since the introduction of e-government in the UK in the mid 1990's, successive governments have defined policies and invested on digital inclusion initiatives with the ambition that all citizens and institutions will have access to digital content and technologies that enable them to create and support healthy, prosperous, and cohesive twenty-first century communities (Cabinet Office 2012). Moreover, to exploit the educational, economic, and social opportunities available through affordable ICTs, successive governments have looked at digital inclusion to support many policy areas 
such as social inclusion, community development, transformational government, product and service accessibility, data sharing and skills. In addition, the UK has always been active to explore ICT and digital inclusion policies to improve efficiency in operational services and cut cost of public services. However, challenges have remained from the beginning (i.e. for the last two decades) leaving important questions unanswered as to how all members of a community benefits equally from digital inclusion policies. Indeed, high usage rates are essential and a prerequisite for successful adoption and diffusion of e-government within a digital-national environment. While $97 \%$ of public services were available online in the UK for the last 8 years since 2010, this has not resulted in greater use of these services by citizens (Seybert 2011; Waller and Weerakkody 2016). By 2013, although $87 \%$ of UK households had Internet access (broadband connection) and $87 \%$ of individuals were regularly using the Internet and $77 \%$ purchased or ordered online, interaction with public authorities did not reach more than $33 \%$ for obtaining information, $22 \%$ for downloading forms, and $22 \%$ for returning filled forms (Information society statistics website 2014). This gap has continued to widen with the UK government's digital by default policy (GDS 2015) - meaning a group that needs public services the most continue to struggle. The resulting calls by stakeholders such as local authorities and citizen advise services to maintain multiple channels of citizen-togovernment interaction, including face-to-face and paperbased transactions, raises the important question of how to balance 'digital by default' with inclusion in the UK.

A review of relevant research over the last decade identifies several factors that influence citizens engagement with egovernment (e.g. costs, trust, lack of skills, lack of access and disinterest) (El-Haddadeh et al. 2019; Mahmood et al. 2019; Cruz-Jesus et al. 2017; Helsper 2008; Helsper 2014; Becker et al. 2008; Carter et al. 2016). However, these factors are not all exclusive to e-government, some address the participation in information society in general (Becker et al. 2008). Becker et al. (2008) has distinguished different steps of participation in the information society by analysing citizens' use of different Internet activities where they identified four gaps between different Internet activities used by citizens in Germany. We draw from Becker's study to look at citizens' use of different Internet activities and level of participation in information society and e-Inclusion based on the latest available data (UK E-Government Fact Sheet 2018). The first gap is between the total population and the Internet users - around $8 \%$ of the UK population never used the Internet. The second gap is between the Internet users and the e-commerce users while around $92 \%$ of individuals use the Internet at least once a week, only around $75 \%$ of the population have used it for buying or ordering goods. The third gap is between the ecommerce users and the e-government users - although around $75 \%$ of the population used e-commerce at least once every 3 months only around $49 \%$ of them have used it for egovernment services (UK E-Government Fact Sheet 2018). This is only a $9 \%$ rise compared to 2014. The fourth gap between people who use e-government for the purpose of information and those who use e-government for the purpose of transactions was omitted since data was not available to assess this. Although Becker's approach was successful in identifying the specific e-inclusion gaps between citizens, the approach could not determine which measures to undertake in order to increase inclusiveness within e-government use. To address this research gap from a theoretical angle and to find out the critical e-Inclusion factors that influence citizens' use of online government services within a digital nation (UK), the present research was undertaken.

Given the parallels between e-government and e-inclusion, it helps to understand how policies, society, organisations, and information technologies come together and how e-Inclusion factors influences e-government use. This is particularly important as there is limited theoretical understanding of the complexities and challenges facing e-inclusion. Given this context, this study aims to answer the research question: What are the key factors that influence e-inclusion in the context of e-government within its digital-by-default environment in the UK? In answering the research question, this study attempts to examine the theoretical and practical intersections of e-inclusion and e-adoption (within a digital by default context) and to extrapolate how they complement and possibly enrich the potential of both e-inclusion and e-government research.

In realise the above, the rest of the paper is structured as follows. The next section presents a brief background to egovernment and conceptualises e-inclusion through a review of relevant theoretical models and discussion of current gaps and challenges in studying e-inclusion. This is followed by the development of a conceptual framework and a set of research hypotheses for evaluating the factors influencing e-inclusion in section 3. Thereafter, the research methodology used for the study is outlined in section 4. A discussion follows in section 6 , which reflects on the empirical results presented in the previous section 5 of a survey of UK citizens. The paper concludes by outlining the main contributions to literature and lessons to policy makers.

\section{Research Context and Theoretical Background}

\subsection{Digital Government and Digital Inclusion: The Context}

It is evident that there is a close linkage between inclusion and digital inclusion (e-inclusion) (Yu et al. 2018; Wright and Wadhwa 2010; Helbig et al. 2009; Kaplan 2005). In this 
regard, e-Inclusion is essentially about social inclusion in a knowledge society (Kaplan 2005). In Europe, e-inclusion remains one of the three strategic pillars of the i2010 inclusion strategic plan, which specifies primary goals of growth, employment, and quality of life (Helbig et al. 2009). The European strategy is to ensure that the benefits of the information society can be enjoyed by everyone, including people who are disadvantaged due to limited resources or education, age, gender, ethnicity disabilities as well as those living in less favoured areas (i2010 European Strategic Plan 2007). According to Wright and Wadhwa (2010) the term einclusion has its roots in European Commission documents published in 1999 in which it is stated that, the objective of einclusion is to bring every citizen, every school, and every company in Europe online.

Definitions of e-inclusion are important for both practice and research. In practice, if e-inclusion is understood as multifaceted then e-inclusion practices will need to reflect this in order to be successful. On the other hand, in e-inclusion research there are dangers in viewing e-inclusion too simplistically (Damarin 2000; Saebø et al. 2008). Therefore, it is important to define the boundaries of e-inclusion and identify the core concepts for e-Inclusion that can cater for a wide range of influencing factors. Within this context, it is also critically importance to distinguish between e-inclusion and e-adoption, (e.g. the uptake of ICT tools and services by the population at large). E-Inclusion is mostly concerned with the social impact of relative differences in ICT use between different socioeconomic groups and individuals while e-adoption focuses instead on absolute and average figures of ICT uptake and their economic impact (Kaplan 2005).

The debate has been ongoing for nearly two decades now about policies such as digital-by-default in the UK and whether they can promote social inclusion through access to government services from anywhere in a transparent, efficient and cost-effective manner (Helsper 2008; Helsper 2012; Helsper 2014; Shelley II et al. 2006; Waller and Weerakkody 2016). Consequently, for e-government to be inclusive, it must reach out to all segments of population with e-services that meet the needs of the digitally disadvantaged. Although e-adoption has a positive impact on e-Inclusion as it draws more people and services online, with a series of positive economic benefits, it is not the case with inclusion. The quantitative growth of the online population may leave out large numbers of groups and individuals. For this reason, e-inclusion should not be reduced to e-adoption, which would only look at levels of ICT at large and miss the social impact of relative differences in ICT use between various socio-economic groups and individuals (Mancinelli 2008). There are many theoretical and empirical difficulties of bringing together e-inclusion and e-government fields. E-Inclusion and e-government fields seem to be moving toward more complex and sophisticated understandings of each phenomenon and there are important similarities between their philosophical stances and theoretical lenses. However, there are relatively few explicit examples of einclusion research findings in published e-government research and vice versa (Helbig et al. 2009). E-Inclusion issues should be considered as important components in egovernment theoretical models, either as assessing the social desirability of information technologies in a certain policy domain, affecting the demand of e-government services, or limiting the usefulness of certain government applications.

\subsection{Conceptualising E-Inclusion: Relevant Theories and Models}

The study of adoption and usage of information technology (IT) is considered to be one of the most mature areas of research within the information systems (IS) discipline (Benbasat and Zmud 1999; Hu et al. 1999; Venkatesh et al. 2003). Subsequently, a number of theories and models have been adopted from diverse disciplines such as social psychology, sociology and marketing, and have been modified, developed and validated by IS researchers in order to understand and predict technology adoption and usage (Benbasat and Zmud 1999; Venkatesh et al. 2003). Theory of Reasoned Action (TRA) (Fishbein and Ajzen 1975); the Theory of Planned Behaviour (TPB) (Ajzen 1991; Ajzen 1988; Ajzen 1985; Ajzen and Fishbein 1980; Ajzen and Madden 1986); the Technology Acceptance Model (TAM) (Davis 1989; Davis et al. 1989); and the Diffusion of Innovation (DOI) Theory (Rogers 1995) are some of the theories and models that have been taken from other disciplines and further modified, extended and integrated according to the needs of IS research. These models usually extend the technology adoption models by including various additional constructs to account for the multi-disciplinary nature of the field. For example, Taylor and Todd (1995) proposed the decomposed TPB by modifying TPB and integrating the diffusion of innovation constructs within it in order to understand various factors in detail. Likewise, Venkatesh and Morris (2000) extended TAM by integrating gender and subjective norm constructs with the original TAM model in order to understand the role of gender and social influence in technology adoption.

A selection of an appropriate model or various constructs from different models posed to be a problem for this research due to the large numbers of choices of theories and models (e. g. TRA, TPB, TAM, DOI). Venkatesh et al. (2003) argued that researchers are confronted with a choice amongst a multitude of models and find that they must "pick and choose" constructs across the models or choose a "favoured model" and largely ignore the contributions from alternative models. Furthermore, it has been noted that there is a missing link between the studies of e-inclusion and e-government adoption, particularly from citizens' perspective. Consequently, through a critical review of these bodies of literature, it has 
been possible to identify six important gaps in the literature, which this study will attempt to fill.

Indeed, several studies have attempted to conceptualise einclusion (see, for example, Becker et al. 2008; Bentivegna and Guerrieri 2010; Hargittai 2004; Hargittai and Hinnant 2008; Helsper 2008; Helsper and Eynon 2010; Mancinelli 2008; Almuwil et al. 2011; Weerakkody et al. 2012). However, Van Dijk (2006) argues rather forcefully that there has been a lack of theorisation in e-Inclusion research. Largely, e-inclusion research has remained at a descriptive level, underlining the demographics of income, education, age, sex, and ethnicity. Consequently, there is a need for deeper research to find out the social, cultural, and psychological causes behind the inequality of access. Many researchers have argued that e-Inclusion has multidimensional constructs, which adds more complexity when attempting to simplify the concept (e.g. Cullen et al. 2007; Codagnone 2009; Wright and Wadhwa 2010). In order to examine the impact of e-inclusion, it is important to identify appropriate assessments and indicative measures. At present, most existing indicators are still centred on broad measurements such as access to ICTs and Internet connection, availability and level of digital literacy skills and ICT usage rates. Although such indicators on eaccess, e-skills and e-usage are useful for national benchmarks and trans-national comparisons, they fail to present an integrated view of the real life worlds of citizens (Cullen et al. 2007). We posit that greater elaboration and refinement of variables is needed in the assessment of e-Inclusion due to is multi-dimensional perspective.

A review of literature indicates that there are a few relevant frameworks that are focused on e-inclusion; while the available frameworks are useful for evaluating the impact of electronic services on general populations, they tend to be less applicable for evaluating the needs of disadvantaged people with more complex needs (Cullen et al. 2007). Bradbrook and Fisher (2004) advocate the ' 5 Cs' of e-Inclusion Connection, Capability, Content, Confidence and Continuity. On the other hand, Van Dijk (2006) was one of the first academics to point out the multi-dimensional aspect of digital divide. He conceptualized access to a fourfold unit that comprises four barriers namely; motivational access, material access, skills access and usage access. Helsper (2008) focusing on digital resources grouped e-inclusion into four broad categories namely; ICT access, skills, attitudes and extent of engagement with technologies. The framework by Verdegem and Verhoest (2008) explains the relation between the socio-demographic and socio-economic characteristics of non-users or the disadvantaged group. Bentivegna and Guerrieri (2010) presented an e-Inclusion Index which is a multi-focus approach. The main objective of this index is to track progress in the development of ICTs and to monitor and capture the level of advancement of e-Inclusion. Table 1 presents a summary of various theories and models adopted in examining e-inclusion.

\section{A Conceptual Model for E-Inclusion}

The literature review found that the lack of conceptual definitions and theoretical frameworks for e-inclusion has prevented the development of reliable measurement and identification of specific factors that influence e-Inclusion. Drawing from the available literature, a conceptual taxonomy of the key inhibitors for e-inclusion can identified, namely: demographical, economic, social, cultural, political, and infrastructural (See Table 2). Notably, these themes emerged in the literature from actual citizens' behaviour in their day-to-day life situations while using electronic-government services.

By combining e-inclusion models and those used in egovernment adoption, a research model is developed in the present study based on the Decomposed Theory of Planned Behaviour (DTPB) and Uses and Gratifications Theory (U\&G). The rationale for choosing these two theories is explained in detail in the following sections (3.1 to 3.4).

\subsection{Uses and Gratifications Theory (U\&G)}

The Use and Gratifications Theory (U\&G) originated from the functionalist perspective on mass media communication. $U \& G$ was first developed in research on the effectiveness of the radio medium in the 1940s. The main focus of $U \& G$-at that time- was on the explanations for audience members' motivations and associated behaviours. Similarly, Herzog (1944) used the term gratifications to depict the specific dimensions of usage satisfaction of radio audiences. Following that, mass communication theorists applied the U\&G perspective in the context of various mass media such as television and electronic bulletins. The U\&G research has been quite fruitful in understanding consumers' motivations and concerns for using various media such as radio, TV, and electronic bulletins (Eighmey and McCord 1998). Many theorists believe that uses and gratifications is a research tradition highly suited for Internet studies (See, Johnson and Kaye 2003; Weiser 2001). U\&G has been widely applied to examine consumer experience associated with websites (Chen and Wells 1999; Korgaonkar and Wolin 1999; Eighmey and McCord 1998; Mukherji et al. 1998). According to Stafford et al. (2004) U\&G guides the assessment of user motivations for media usage and access and explains how needs motivate individual's adoption of information technology. Moreover, $\mathrm{U} \& \mathrm{G}$ has increasingly being used to investigate the adoption of web-based information services (Stafford et al. 2004; Diddi and LaRose 2006; Ko et al. 2005; Moon and Kim 2001). A basic assumption of $U \& G$ theory is that users are actively involved in media usage and interact highly with the communication media. Since the interactive nature of the Web requires high user involvement, the application of uses and gratification theory to improve our understanding of eInclusion and e-government users' behaviour seems legitimate. 
Table 1 various theories and models adopted for e-inclusion

\begin{tabular}{|c|c|c|c|}
\hline & heories \& Models & Description & Reference \\
\hline & The' 5 Cs' of e-Inclusion & $\begin{array}{l}\text { Referred to as the ladder model, this framework emphasises the complexity of } \\
\text { e-Inclusion by identifying five criteria that influence e-Inclusion: } \\
\text { - Connectivity(access) } \\
\text { - Capability(skills) } \\
\text { - Content } \\
\text { - Confidence (self-efficacy) } \\
\text { - Continuity }\end{array}$ & $\begin{array}{l}\text { Bradbrook and } \\
\text { Fisher (2004) }\end{array}$ \\
\hline 2 & $\begin{array}{l}\text { A cumulative and recursive model of successive } \\
\text { kinds of access to digital technologies }\end{array}$ & $\begin{array}{l}\text { Dijk (1999) was one of the first researchers to point out the multifaceted aspect of the } \\
\text { digital divide. He conceptualized access to a fourfold unit that comprises } 4 \text { barriers: } \\
\text { - Motivational Access: limited take up of ICT, lack of interest and negative attitude. } \\
\text { - Material Access: Lack of actual ICT material } \\
\text { - Skills Access: Lack of digital skills, low user friendliness of ICT, lack of education \& } \\
\text { social support networks } \\
\text { - Usage Access: Lack of usage opportunities \& the uneven spread of this opportunities } \\
\text { across societies }\end{array}$ & $\begin{array}{l}\text { Van Dijk, }(2005 ; \\
\quad(2005)\end{array}$ \\
\hline 3 & Framework of digital resources & $\begin{array}{l}\text { This frameworks look s at digital disengagement as determined by either exclusion, } \\
\text { factors and barriers that are not easy for an individual to overcome quickly themselves } \\
\text { (for example, low income and poor infrastructure availability) or by digital choice } \\
\text { (that is if the person chooses not to use technologies even though they have the } \\
\text { capabilities to do so). } \\
\text { Digital resources are grouped into four broad categories: } \\
\text { - ICT Access } \\
\text { - Skills } \\
\text { - Attitudes } \\
\text { - Extent of engagement with technologies }\end{array}$ & Helsper (2008) \\
\hline 4 & The 'ASA-profile' \& relative utility theory & $\begin{array}{l}\text { This approach is articulated around the concept of 'relative utility'. It attempts to set up } \\
\text { effective e-Inclusion measures. The advantage of this method is that groups of indi- } \\
\text { viduals with relatively homogeneous ASA-profile can easily be identified and reached } \\
\text { by policy makers. A specific offering can then be proposed to these groups, taking into } \\
\text { account the specificities of their ASA-profile and socio-economic background. ASA } \\
\text { refers to: } \\
\text { - Access: access to ICT } \\
\text { - Skills: skills to master the devices } \\
\text { - Attitude: attitude toward to technology }\end{array}$ & $\begin{array}{l}\text { Verdegem and } \\
\text { Verhoest } \\
(2008)\end{array}$ \\
\hline 5 & E-Inclusion Index - multi focus approach & $\begin{array}{l}\text { The main objectives of the index are to track progress in the development of ICTs and to } \\
\text { monitor and capture the level of advancement of e-Inclusion. The analytical } \\
\text { framework underlying the construction of the e-Inclusion index is structured into three } \\
\text { components (dimensions of the general concept: access, usage, impact on quality of } \\
\text { life) and into twelve sub-indexes: } \\
\text { - Internet access: network, affordability, availability and quality. } \\
\text { - Internet usage: Autonomy, intensity, skills. } \\
\text { - Internet impact: eEducation, eHealth, eLabour, eGovernment, eEconomic, eCulture and } \\
\text { communication. }\end{array}$ & $\begin{array}{l}\text { Bentivegna and } \\
\text { Guerrieri } \\
(2010)\end{array}$ \\
\hline
\end{tabular}

U\&G studies on the Internet have identified multiple dimensions of Internet usage gratifications. For example, Stafford et al. (2004) have identified three key dimensions related to consumer use of the Internet and they are; process gratification (e.g., playing with the technology, resources, search engines, browsing), content gratification (e.g., information, education, knowledge, learning, research and entertainment), and social gratification (chatting, friends, interaction, and people). Content gratifications concern the messages carried by the medium, and processes gratifications concern actual use of the medium itself. Finally, the social gratifications which concern the interaction have been identified by Stafford as a new dimension of Internet gratification. Stafford dimensions of $U \& G$ is adopted for this study to
Table 2 Key inhibitors for eInclusion in the context of egovernment

\begin{tabular}{lllll}
\hline Theme & Factor 1 & Factor 2 & Factor 4 & Factors 5 \\
\hline Social & Language & Knowledge & Traditions & Skills \& IT skills \\
Demographic & Age & Gender & Race \& Ethnicity & Marital Status \\
Infrastructural & Urbanization & Resources & Access & Lifestyle \\
Cultural & Education & Health & Motivation & \\
Political & Government support & Accessible information & Legislations & \\
\hline
\end{tabular}


construct the conceptual basis and research hypothesis for the arguments presented in this research. The reason behind adopting Stafford dimensions that he identified three key dimensions of gratifications related specifically to consumers' use of the Internet as a medium. Moreover, the important contribution of Stafford was the identification of the social gratification construct which provides opportunities for the advancement of Internet access services.

Scholars have also argued that e-inclusion is not merely about digital access, digital literacy, or cost anymore. Fuchs (2009) posits that there are groups of people who although having access and skills to use the internet and egovernment services, do not do so because they don't see the relevance of, or do not trust in government websites. Therefore, understanding the citizens' motivations and gratifications to use the Internet is a critical factor in the context of e-Inclusion and e-government adoption. In this respect, U\&G can help to better understand citizens' motivation for e-government use (Ruggiero 2000). This study suggests that citizens use the Internet for several reasons. The Internet usage for different gratifications are associated with the level of e-Inclusion and the four stages of egovernment development (information available online, one-way interaction, two-way interaction, and full online transaction) because there is inherent interrelation between degree of use and degree of gratification (Johnson and Kaye 2003). These gratifications can be divided into three dimensions based on Internet-specific U\&G measures which have been demonstrated in the management information system literature (Stafford et al. 2004; Stafford and Stafford 2001). The first dimension covers gratifications based on the content of the Internet (content gratifications) which is related to the repeated use of a media. The second dimension covers gratifications based on the actual experience of using the Internet (process gratifications). The third dimension covers gratifications arising from Internet use as a social environment and provides communication and interaction (social gratifications). Fuchs (2009) called lack the interest for using the Internet, ecommerce or egovernment "motivational access". This psychological aspect of the e-Inclusion is often neglected in literature (Fuchs 2009; Bruno et al. 2010). Moreover, motivational access is the first stage in Van Dijk $(2005 ; 2006)$ cumulative "successive types of access" model. In this model the concept of access evolves into successive types of access to digital technologies: motivational access, physical access, skills access, and usage access. According to Van Dijk's model, adoption starts with sufficient attractiveness of the innovation and the motivation for adoption. These arguments in the literature offer a strong justification for the author to consider U\&G as a conceptual lens to study eInclusion. In Table 3, various uses of U\&G theory in IS studies is presented.

\subsection{Decomposed Theory of Planned Behaviour (DTPB)}

The DTPB (Taylor and Todd 1995) is derived from the theory of planned behaviour (Ajzen 1991) with its fundamental belief and structure (See Fig. 3). Taylor and Todd (1995) have proposed the DTPB to explain user's acceptance of information system. The DTPB term exactly means that this theoretical model can explore more completely the dimensions of attitudes, subjective norm, and perceived behavioural control in TPB by decomposing them into specific belief dimensions (Taylor and Todd 1995). Later, several studies have also accepted this term to explore user acceptance of a range of information systems (Chau and Hu 2001; Hsu and Chiu 2004). Consequently, DTPB is expected to provide a more comprehensive understanding of user acceptance of intergovernmental e-government services for e-government services practitioners and researchers. This study adopted the decomposed theory of planned behaviour (DTPB) for the following reasons. First the DTPB was developed especially for understanding information technology use (Taylor and Todd 1995) and effectively explained individual intentions and behaviour in adopting e-government services (Hung et al. 2006) and mobile services (Yulong and Wenli 2009). In DTPB, attitude, subjective norm, and perceived behavioural control are further decomposed into some more specific constructs (Lau and Kwok 2007). Taylor and Todd (1995) demonstrated that DTPB has the enhanced descriptive power than theory of reason action and TPB models. Moreover, DTPB provides a better gratifying explanation of adoption intention (Shih and Fang 2004), a complete understanding of usage, and a complete understanding of adoption behaviour (Lau and Kwok 2007). The DTPB allows researchers to decompose the attitudinal, normative and control categories to better understand the reasons of adoption and non- adoption (Taylor and Todd 1995).

In this research, usage behaviour in the e-inclusion model is determined by behavioural intention, gratifications and the three major determinants: attitude, subjective norm, and perceived behavioural control which are used to determine the behavioural intention. The three major determinants are further decomposed into detailed belief constructs. Perceived usefulness, perceived ease of use and compatibility are the constructs that determine attitude. Interpersonal influence, media influence, and government influences are the constructs that determine subjective norm. Capacity, accessibility, affordability, and availability are the constructs that determine perceived behavioural control. According to DiMaggio and Hargittai (2001) inequality in e-Inclusion encompasses five main variables: technical means; autonomy; skill; social support; and purpose. In this study, we propose $U \& G$ to cover the purpose variables and DTPB to cover the technical, autonomy, skill, and social variables. Access is fundamental and 
Table 3 Constructs definition and sources

\begin{tabular}{|c|c|}
\hline Construct & Definition \\
\hline Attitude & Individual's evaluation of the behaviour of interest \\
\hline Perceived Ease of Use & $\begin{array}{l}\text { The degree to which an individual believes that performing the behaviour of interest } \\
\text { would be free of effort }\end{array}$ \\
\hline Perceived Usefulness & $\begin{array}{l}\text { The degree to which an individual believes that using the system will help him or her } \\
\text { to attain gains in life or job performance. }\end{array}$ \\
\hline Compatibility & $\begin{array}{l}\text { The degree to which the innovation fits with the potential adopter's existing values, } \\
\text { previous experiences, and current needs }\end{array}$ \\
\hline $\begin{array}{l}\text { Perceived Content } \\
\text { Gratification }\end{array}$ & $\begin{array}{l}\text { people use Internet activities for the content carried by a medium (e.g., information, } \\
\text { learning, education, knowledge) }\end{array}$ \\
\hline $\begin{array}{l}\text { Perceived Process } \\
\text { Gratification }\end{array}$ & $\begin{array}{l}\text { people use Internet activities for the simple experience of the media usage process } \\
\text { (e.g., searching, surfing, technology) }\end{array}$ \\
\hline $\begin{array}{l}\text { Perceived Social } \\
\text { Gratification }\end{array}$ & $\begin{array}{l}\text { People use Internet activities for social purpose (chatting, live interaction, and } \\
\text { interaction with people in general) }\end{array}$ \\
\hline $\begin{array}{l}\text { Perceived Behaviour } \\
\text { Control }\end{array}$ & $\begin{array}{l}\text { An individual's perception of existence or nonexistence of required resources and } \\
\text { opportunities to perform the behaviour of interest }\end{array}$ \\
\hline Accessibility & $\begin{array}{l}\text { It refers to the ease with which individual can locate software and hardware required } \\
\text { to engage in a behaviour from any location, at any time of the day }\end{array}$ \\
\hline Affordability & The availability of financial resources needed to engage in a behaviour. \\
\hline Capacity & An individual's self-confidence in his ability to perform a behaviour. \\
\hline Availability & $\begin{array}{l}\text { The availability of financial resources needed to engage in a behaviour. It include } \\
\text { adequate hardware,platforms and high speed Internet connection required to } \\
\text { engage in a behaviour }\end{array}$ \\
\hline Subjective Norm & $\begin{array}{l}\text { The perceived expectation from an individual's key referents to perform the } \\
\text { behaviour of interest }\end{array}$ \\
\hline $\begin{array}{l}\text { Governmental } \\
\text { Influence }\end{array}$ & $\begin{array}{l}\text { The perceived expectation from the government institutions for individuals to } \\
\text { perform the behaviour of interest. }\end{array}$ \\
\hline Media Influence & $\begin{array}{l}\text { The perceived expectation from the media for individuals to perform the behaviour of } \\
\text { interest }\end{array}$ \\
\hline Interpersonal Influence & $\begin{array}{l}\text { The perceived expectation from family, relatives, friends and peers for an individual } \\
\text { to perform the behaviour of interest. }\end{array}$ \\
\hline Behaviour Intention & $\begin{array}{l}\text { The degree to which a person has formulated conscious plans to perform or not } \\
\text { perform some specified future behaviour. }\end{array}$ \\
\hline Use Duration & Represents the amount of time spent using Internet \\
\hline Use Frequency & How often do you use the Internet \\
\hline Use Intensity & How do you consider the extent of your current Internet use \\
\hline Satisfaction & $\begin{array}{l}\text { Satisfaction is individuals' feelings of pleasure or disappointment resulting from } \\
\text { comparing their perceptions of a product or service's performance to their } \\
\text { expectation levels. In the final step of satisfaction formation processes, satisfaction } \\
\text { determines intentions to patronize or not to patronize the store in the future }\end{array}$ \\
\hline Continuity & The intention to continue using the technology \\
\hline Trust in e-government & $\begin{array}{l}\text { Individuals' willingness to rely on e-government websites for obtaining information } \\
\text { or conducting government transactions based on the feelings of confidence or } \\
\text { assurance. }\end{array}$ \\
\hline Trust in Internet & $\begin{array}{l}\text { Individuals' willingness to rely on technology based on the feelings of confidence or } \\
\text { assurance. }\end{array}$ \\
\hline
\end{tabular}

basic to e-inclusion. According to Van Dijk (2005; 2006), the concept of access evolves into successive types of access to digital technologies: motivational access, physical access, skills access, and usage access. Motivational access is covered by the U\&G, physical access is covered by accessibility, skill access is covered by capacity, and usage access is covered by the behavioural intention in DTPB.

\subsection{Conceptual Framework}

To explore the factors that influence e-inclusion in the context of digital-by-default for government services in the UK, $\mathrm{U \& G}$, DTPB, trust and risk are integrated to propose the research model for e-inclusion. (DTPB) is adapted from social psychology and integrated with the $(U \& G)$ in addition to 
theoretical findings from prior e-inclusion research to theorize a model of e-inclusion. Specifically, the research model brings together all (DTPB) constructs from the literature without the fear of losing theoretical plausibility of the model. The research model decomposes the perceived behavioural control components of (DTPB) into accessibility, affordability, availability, and capacity, the subjective norm component into interpersonal influence, media influence and government influence, and the attitude component into perceived usefulness, perceived ease of use, and compatibility. Three gratifications construct has been added to the model; process gratification, content gratifications, and social gratifications. Trust in e-government, trust in Internet and perceived risk were added to the model subsequently after conducting a pilot study. Finally, the use is examined in terms of two key conceptualisations; frequency, and intensity. Figure 1 outlines the research model that will examine the factors that influence e-Inclusion in the context of the UK by combining (U\&G) with (DTPB). In this research, Stafford et al. (2004) gratification dimensions have been adopted. He identified three key dimensions of gratifications related to consumers' use of the Internet; process gratifications (e.g., resources, search engines, searching for specific information, technology, website), content gratifications (e.g., information, education, knowledge, learning, research), and social gratifications (live chatting, interaction, and social interaction with people in general). The important contribution of Stafford was the identification of the social gratification construct which provides opportunities for the advancement of Internet access services. Content gratifications concern the messages carried by the medium, and processes gratifications concern actual use of the medium itself (Cutler and Danowski 1980). Moreover, the social gratifications for the Internet concern with the interaction (Stafford et al. 2004). Consistent with DTPB, the proposed model of e-inclusion consists of three predictor types, namely attitudinal beliefs, normative beliefs and control beliefs and dependent variables that include behavioural intention (BI), content gratifications, process gratifications, social gratifications, use behaviour,
Fig. 1 The proposed research model

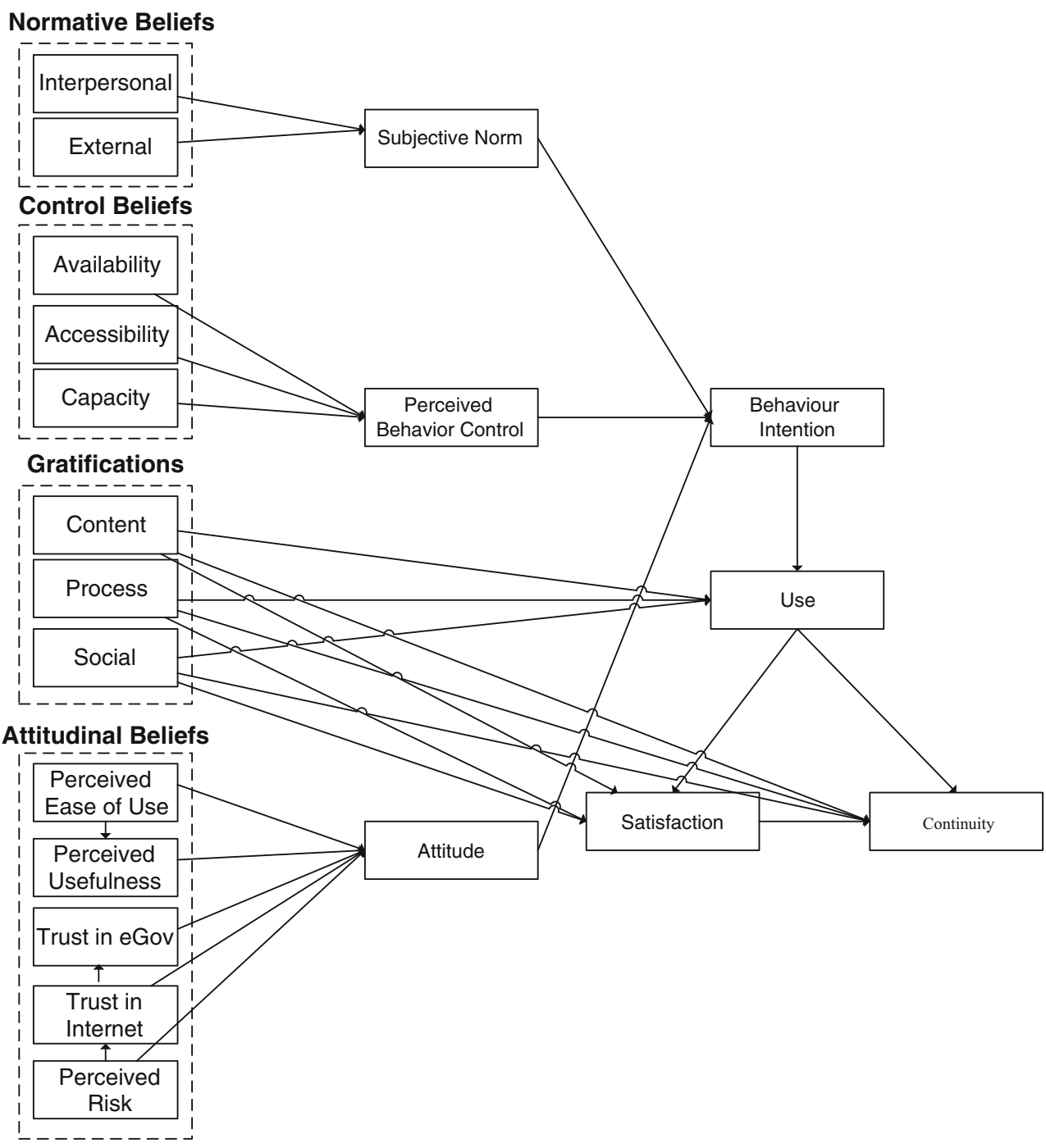


satisfaction, and continuity. Since TPB is a generalised theory and can be applied to a wide variety of contexts for predicting the adoption of different types of IT (Benbasat and Zmud 1999), the relationship between dependent and independent variables is hypothesised according to TPB. Therefore, TPB is considered a basic guiding theory for this research. The components of the proposed model hypothesises that the behavioural intention to use behaviour is determined by the following four types of constructs: (1) attitudinal constructs (COMP, PEOU, PU) represent the citizens' favourable or unfavourable evaluation of the behaviour in question (i. e. use of e-government services); (2) normative constructs (Interpersonal influence, media influence, and government influence) represent the perceived pressure by family, friends, media, and government to perform the behaviour in question; (3) control constructs (Capacity, availability, affordability, and accessibility) represent the perceived control over the personal or external factors that may facilitate or constrain the behavioural performance (Tam et al. 2018; Ajzen 1991; Rogers 1995; Taylor and Todd 1995); (4) gratifications (content gratifications which represents gratifications related to the repeated use of a media, process gratifications which represent gratifications based on the actual experience of using the Internet, and social gratifications which arise from Internet use as a social environment and provide communication and interaction). The predictor variables from the four categories are expected to determine and explain the behaviour intention to adopt and use e-government, which in turn is expected to predict the actual use behaviour (Ajzen 1991; Rogers 1995; Taylor and Todd 1995). A list of constructs with definition of each construct is presented in Table 3 .

\subsection{Research Hypothesis}

There are thirty distinct relationships that can be identified from the conceptual framework and it is important to explore these relationships. The proposed research model includes; six variables affecting attitude, three variables affecting subjective norm, and four variables affecting perceived behavioural control. The selection of these variables is supported by previous studies in IS or e-Inclusion literature. Figure 1 illustrates the research model and hypotheses for e-Inclusion in the context of e-government based on U\&G and DTPB. The focus for both theories is explaining user acceptance and use of technology. Citizens' behavioural intention towards e-government use has been usually examined by drawing on the concept of various technology acceptance models without sufficient attention being given to other factors (Lean et al. 2009). In this context, $U \& G$ has been quite effective in explaining motivations and needs for using the Internet (Ko et al. 2005; Korgaonkar and Wolin 1999; Papacharissi and Rubin 2000). The DTPB allows researchers to decompose the attitudinal, normative and control categories to better understand the reasons of adoption and non- adoption (Taylor and Todd 1995). However, some scholars have criticized user acceptance models for their inability to better account for the factors that explain users' motivations toward technology. For example; Davis (1989) argues that research should also incorporate additional variables that could affect user acceptance. Therefore, in this study we extend DTPB to include motivational constructs from $U \& G$ to study e-inclusion. Moreover, in our proposed conceptualization and hypothesis development, we include three additional constructs (perceived trust, perceived risk, satisfaction, and continuity) to better understand the factors that influence citizens' e-inclusion. In this study, $U \& G$ focuses on individual levels of psychological needs and motivations. U\&G suggests that citizens' selection and continuance use of the Internet activities (specifically, egovernment) is based on their needs or gratification. In our conceptualization, we propose that content, process and social gratifications affects citizens' attitude toward using the e-government. We posit that different users are driven by different motivations and the understanding of why people do not adopt or do not use ICT is strongly relevant in the light of the development of an inclusive information society. Table 4 draws from seminal literature and presents the hypothesis for this study.

\section{Methodology}

To test the proposed hypotheses, we used a survey-based research within a quantitative paradigm (Creswell 2008) with a Likert scale (Bryman and Bell 2011) for rating the questions when collecting the respondent's opinion. A seven-point rating scale is used in where 1 is extremely disagree and 7 is extremely agree. Both positive and negative questions are used to ensure that the respondents read each question carefully and think about which scale to select (Saunders et al. 2011). As the aim of this research was to examine the factors affecting e-inclusion in the context of digital-by-default in the UK, collecting data from as many participants from across the country is required. Thus, the survey approach was selected for the study and the sampling frame constituted citizens from across the UK (south, west, north, and east) representing an overall sample of the population. To institute the sample frame of citizens, a list of respondents was selected from all different backgrounds including students, housewives, employees, unemployed individuals, pensioners. Furthermore, due to the reason that not every unit (i.e. citizens) of the population is guaranteed to be selected in the sample, the survey was voluntary where only the interested respondents were invited to take part. Moreover, as this study focusing on e-inclusion, the survey has been designed to consider the responses of only the Internet adopters and potential adopters of the e-government services. 
Table 4 Research hypotheses

\begin{tabular}{|c|c|c|c|}
\hline \multicolumn{2}{|c|}{ Hypothesis } & \multirow{2}{*}{$\begin{array}{l}\text { Motivation } \\
\text { Individual perceived usefulness and ease of use are } \\
\text { important determinants of individual acceptance of } \\
\text { information technology }\end{array}$} & \multirow{2}{*}{$\begin{array}{l}\text { Supporting studies } \\
\text { Davis (1989); Taylor and Todd (1995) }\end{array}$} \\
\hline $\mathrm{H} 1$ & $\begin{array}{l}\text { Perceived usefulness } \\
\quad \rightarrow \text { attitude }\end{array}$ & & \\
\hline $\mathrm{H} 2$ & $\begin{array}{l}\text { Perceived ease of use } \\
\quad \rightarrow \text { attitude }\end{array}$ & PEOU influence intentions over attitudes & Davis (1989); Taylor and Todd (1995) \\
\hline H3 & $\begin{array}{l}\text { Perceived ease of use } \\
\quad \rightarrow \text { perceived }\end{array}$ & $\begin{array}{l}\text { Effect of PEOU on behavioural intention, either directly or } \\
\text { indirectly through its effect on perceived usefulness }\end{array}$ & Davis (1989); Taylor and Todd (1995) \\
\hline
\end{tabular}

usefulness usefulness
H4a Trust in attitude

Trust in e-government influences attitude

Karavasilis et al. (2010)

H4b Trust in e-government $\rightarrow$
perceived behav-

iour control

H5a Perceived risk $\rightarrow$ attitude

Trust in e-government influences perceived behaviour control

How individuals become alarmed about different types of risks when engaged in Internet activities

H5b Perceived risk $\rightarrow$ trust in e-government

H6a Trust Internet $\rightarrow$ Trust in e-government

H6b Trust Internet $\rightarrow$ attitude

H7 Compatibility $\rightarrow$ attitude

H8 Accessibility $\rightarrow$ perceived behaviour control

Capacity $\rightarrow$ perceived behaviour control

H10 Availability $\rightarrow$ perceived behaviour control

H11 Affordability $\rightarrow$ perceived behaviour control

H12 Interpersonal influence $\rightarrow$ subjective norms

H13a Media influence $\rightarrow$ subjective norms

H13b Gov. Influence $\rightarrow$ subjective norms

H14a Content gratifications $\rightarrow$ Use

\section{H14b Content gratifications $\rightarrow$ Satisfaction}

H14c Content gratifications $\rightarrow$ Continuity
Risk comes to mind as a natural extension of trust

The environment in which the interaction and transactions take place when using the internet to access e-government services

citizens perceive the safety measures - such as encryption of sensitive data, or the legal frame work surrounding online transactions -will be more likely to use the e-government services

Increased compatibility of information technologies leads to a more positive attitude towards information systems usage

User perceptions of accessibility have been found to be related to technology and information use

Capacity has long been suggested as the key determinant for behavioural control. It is critical in understanding digital inequality

Availability of financial and technological resources to engage and promote e-government services

Affordability of financial resourcesto engage and promote e-government services

Interpersonal influence is direct in nature and exerted by friends, peers, family members and relatives who are expected to have a strong influence when performing certain behaviour

The perceived expectation from the media for individuals to perform the behaviour of interest

The perceived expectation from the government institutions for individuals to perform the behaviour of interest

How motivation influence behavioural usage without the mediation effects of attitude or behavioural intention. It looks at the acceptance and usage of IT from purely motivational perspectives.

How motivation of contents influence behavioural aspects Oliver (1980); Swan and Trawick, (1981) including satisfaction

How motivation of contents influence behavioural aspects Swan and Trawick, (1981) and continuity
Zafiropoulos et al. (2012)

Gefen et al. 2003; Featherman and Pavlou 2003

Bélanger and Carter (2008)

Karavasilis et al. (2010); Zafiropoulos et al. (2012)

Gefen et al. (2003)

Taylor and Todd (1995)

Kvasny and Keil (2006)

Bandura (1986); Ajzen (1991); Taylor and Todd (1995); Bhattacherjee (2000)

Hsieh, Rai, and Keil (2011); Bandura (1986); Ajzen (1991); Taylor and Todd (1995); Bhattacherjee (2000)

Kvasny and Keil (2006)

Fishbein and Ajzen (1975); Ajzen (1991); Taylor and Todd (1995); Bhattacherjee (2000); Chu et al. (2004)

Fishbein and Ajzen (1975); Ajzen (1991); Taylor and Todd (1995); Bhattacherjee (2000); Chu et al. (2004)

Karahanna et al. (1999); Lynne et al. (1995);

Luo et al. (2011) 
Table 4 (continued)

\begin{tabular}{|c|c|c|c|}
\hline \multicolumn{2}{|c|}{ Hypothesis } & \multirow{2}{*}{$\begin{array}{l}\text { Motivation } \\
\text { concern with the actual use of the medium itself }\end{array}$} & \multirow{2}{*}{$\begin{array}{l}\text { Supporting studies } \\
\text { Luo et al. (2011) }\end{array}$} \\
\hline H15a & $\begin{array}{l}\text { Process } \\
\text { gratifications } \rightarrow \\
\text { Use }\end{array}$ & & \\
\hline $\mathrm{H} 15 \mathrm{~b}$ & $\begin{array}{l}\text { Process } \\
\quad \text { gratifications } \rightarrow \\
\text { Satisfaction }\end{array}$ & concern with the actual use of the medium itself & Oliver (1980); Swan and Trawick, (1981) \\
\hline $\mathrm{H} 15 \mathrm{c}$ & $\begin{array}{l}\text { Process } \\
\quad \text { gratifications } \rightarrow \\
\text { Continuity }\end{array}$ & concern with the actual use of the medium itself & Swan and Trawick, (1981) \\
\hline H16a & $\begin{array}{l}\text { Social gratifications } \\
\quad \rightarrow \text { Use }\end{array}$ & $\begin{array}{l}\text { concern with the interaction when using the medium } \\
\text { through chatting, interacting with others including } \\
\text { people }\end{array}$ & Stafford and Stafford $(2001,2004)$ \\
\hline $\mathrm{H} 16 \mathrm{~b}$ & $\begin{array}{l}\text { Social gratifications } \\
\rightarrow \text { Satisfaction }\end{array}$ & $\begin{array}{l}\text { concern with the interaction when using the medium } \\
\text { through chatting, interacting with others including } \\
\text { people }\end{array}$ & Oliver (1980); Swan and Trawick, (1981) \\
\hline H116c & $\begin{array}{l}\text { Social gratifications } \\
\rightarrow \text { Continuity }\end{array}$ & $\begin{array}{l}\text { concern with the interaction when using the medium } \\
\text { through chatting, interacting with others including } \\
\text { people }\end{array}$ & Swan and Trawick, (1981) \\
\hline H17 & $\begin{array}{l}\text { Attitude } \rightarrow \\
\text { behaviour } \\
\text { intention }\end{array}$ & $\begin{array}{l}\text { Attitude to use advance Internet activities (e.g., } \\
\text { e-government, e-banking, e-shopping), which will } \\
\text { ultimately influence actual usage behaviour }\end{array}$ & $\begin{array}{l}\text { Ajzen (1991); Liao et al. (1999); Chau and Hu (2001); } \\
\text { Chau and Hu (2001); Taylor and Todd (1995); } \\
\text { Bhattacherjee (2000); Mathieson (1991); Hsieh et al. } \\
\text { (2011) }\end{array}$ \\
\hline H18a & $\begin{array}{l}\text { Perceived } \\
\text { behavioural } \\
\text { control } \rightarrow \\
\text { behaviour } \\
\text { intention }\end{array}$ & $\begin{array}{l}\text { Perceived behavioural aspects towards advance Internet } \\
\text { activities (e.g., e-government, e-banking, e-shopping), } \\
\text { which will ultimately influence actual usage behaviour }\end{array}$ & $\begin{array}{l}\text { Ajzen (1991); Liao et al. (1999); Chau and } \mathrm{Hu}(2001) \text {; } \\
\text { Chau and } \mathrm{Hu} \text { (2001); Taylor and Todd (1995); }\end{array}$ \\
\hline $\mathrm{H} 18 \mathrm{~b}$ & $\begin{array}{l}\text { Subjective norms } \rightarrow \\
\quad \text { behaviour } \\
\text { intention }\end{array}$ & $\begin{array}{l}\text { Subjective norms influence towards advance Internet } \\
\text { activities (e.g., e-government, e-banking, e-shopping), } \\
\text { which will ultimately influence actual usage behaviour }\end{array}$ & $\begin{array}{l}\text { Ajzen (1991); Liao et al. (1999); Chau and Hu (2001); } \\
\text { Chau and Hu (2001); Taylor and Todd (1995); }\end{array}$ \\
\hline H19 & $\begin{array}{l}\text { Behaviour intention } \\
\quad \rightarrow \text { Use }\end{array}$ & $\begin{array}{l}\text { How actual usage behaviour is influenced directly by } \\
\text { behaviour intention }\end{array}$ & Lou et al. (2011) \\
\hline $\mathrm{H} 20$ & Use $\rightarrow$ Satisfaction & $\begin{array}{l}\text { Positive experience with "use" will lead to greater "user } \\
\text { satisfaction" }\end{array}$ & Venkatesh et al. (2013) \\
\hline $\mathrm{H} 21$ & Use $\rightarrow$ Continuity & $\begin{array}{l}\text { effective reactions of individuals toward the usage of ICT } \\
\text { applications and how this can be successful }\end{array}$ & Swan and Trawick, (1981) \\
\hline $\mathrm{H} 22$ & $\begin{array}{l}\text { Satisfaction } \rightarrow \\
\text { Continuity }\end{array}$ & $\begin{array}{l}\text { Verifying how user satisfaction as a measure of acceptance } \\
\text { and adoption success }\end{array}$ & Swan and Trawick, (1981) \\
\hline
\end{tabular}

In this context, convenience sampling was used to draw from the part of the population that is close to hand, readily available, obtainable, or suitable to the researcher to conduct (Bhattacherjee 2000). The researchers handed out the questionnaire physically to the participants in different locations concentrated community markets, community schools, public library, cafes, universities, and public transportation (trains) and collected the completed questionnaires subsequently. This resulted in a well distributed sample in terms of demographic information. Moreover, this enabled the researchers to clarify any ambiguity to participants enabling them to understand the importance of the research, can encourage a higher response rate. Structural equation modeling (SEM) (Tabachnick and Fidell 2001; Comrey and Lee 1992; Schaupp et al. 2010; Horst et al. 2007; Hung et al. 2009) was used for data analysis from a collected sample of 510 surveys.
Following ethical guidelines, respondents were ensured about the anonymity of their personal information and advised not to reveal any of their personal information on the questionnaire. All the questions were close-ended to make sure that the respondents did not face any difficulty while responding. Prior to the actual data collection, a pilot study was conducted. This pilot study aimed both to evaluate the level of content validity and to ensure that the instructions, questions and scale items were clear. Seventy copies of the questionnaire were distributed through personal contacts on a convenience sample. Fifty-six valid responses were acquired with response rate of $80 \%$. To test the reliability of the items measuring the same construct, Cronbach's $\alpha$ was calculated for these items. After collecting the questionnaires, suggestions for possible improvements and appropriate modifications were discussed with respondents. According to Gliem and Gliem (2003), a 
factor loading between seventy to $80 \%$, points to a good internal consistency, whereas a loading above $80 \%$ indicates an excellent internal consistency. The $\alpha$ tests revealed that all constructs except for one had $\alpha$ values above $70 \%$, revealing that all constructs had good internal consistency. The instrument was refined to increase the $\alpha$ values, after which nine items were removed from the instrument, leaving 63 items. Factorial validity could not be assessed at this stage because of the sample size requirements. The questionnaire was altered to eliminate any possible misunderstandings due to wording. Description of some tasks and minor wording details in survey items have been altered according to the feedback from the subjects.

\section{Results and Analysis}

A total of 800 questionnaires were distributed and 570 questionnaires were returned, which included 60 incomplete questionnaires, leaving a total of 510 usable questionnaires representing a response rate of $63.75 \%$ - an effective response rate within the field of IS research (Cornford and Smithson 2006). The results highlight that average respondent's age ranged from 18 to 74 or above, with males accounting for $48.4 \%$ and females $51.6 \%$ of the sample. Half of the respondents $(50.5 \%)$ were employed and held a secondary school degree (or above). Of the 510 respondents, 358 (70.2\%) were e-government users and 152 (29.8\%) were Internet users but not e-government users. Table 5 presents the demographic data obtained from the respondents.

Table 5 Respondents' demographic profile

Percentage $(\%)$

\begin{tabular}{lll}
\hline Age & $18-24$ & 11.6 \\
& $25-34$ & 20.2 \\
& $35-44$ & 20 \\
& $45-54$ & 20 \\
Gender & $55-64$ & 16.1 \\
& 65 and above & 20.2 \\
Employment & Male & 48.4 \\
& Female & 51.6 \\
& Full time & 39.0 \\
Education & Part time & 16.9 \\
& Retired & 20.4 \\
& Unemployed & 19.2 \\
Geographic Location & Student & 4.5 \\
& Primary & 1.8 \\
Type on Users & Secondary & 50.5 \\
& Undergraduate & 32.0 \\
& Postgraduate & 15.7 \\
& Urban & 28.6 \\
& Suburban & 55.1 \\
& Rural & 16.3 \\
& E-Government Users & 70.2 \\
& Non Users & 29.2 \\
\hline
\end{tabular}

With regard to digital-by-default services, seven egovernment services were listed at the beginning of the questionnaire to give a clear idea to the respondents about some of the digital government services provided by the UK government. These services were selected carefully by the researchers. This included; Council Tax, Inland Revenue, Driving License, Register to Vote, Register with GP, Apply for School Public e-Library services (see Fig. 2 for breakdown of their use). 382 ( $74.9 \%$ ) of them have accessed government services online in the last 12 months.

Becker's approach to identifying E-Inclusion gaps in the context of Germany was applied to the UK using secondary data (Eurostat and UK office for national statistics). The results indicate that both the UK and Germany share the same eInclusion gaps. Four e-Inclusion gaps were identified, and the deepest gap is between e-commerce users and e-government users. The same approach was applied to the research data which was collected from citizens in different cities in the UK. The findings in the UK were consistent with the German results. Moreover, a new gap was identified between use of e-commerce and use of e-banking (See Fig. 3) and this indicates and assures that e-government is the deepest gap among other Internet activities.

A conclusion can be drawn from the above findings; the factors that determine and influence people to use egovernment in general and e-government for transaction will help to address and better explain the factors that influence eInclusion and better explain possible inclusion gaps. There are many reasons behind the above differences in using different Internet activities that need to be clarified and which this research aimed to examine. First, a clarification needs to be made regarding the sample used for this research. The sample consists mainly Internet users, this was purposely to help fulfil the aim of this research. $40 \%$ of the respondents come from age group 25-44 and the rest of the group is older than 44 .

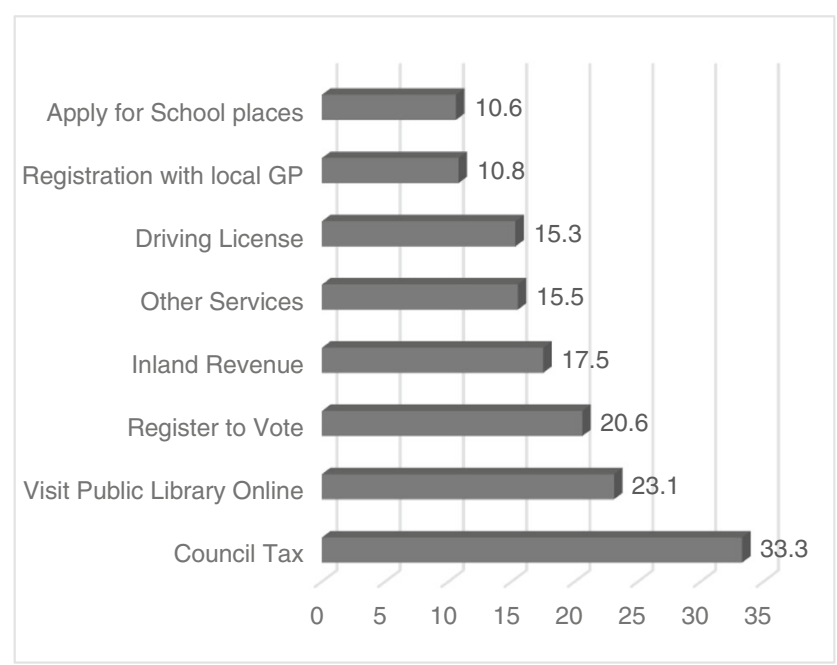

Fig. 2 Overview of citizens use of e-government services in the UK 


\section{Level of E-Inclusion Gaps Model}

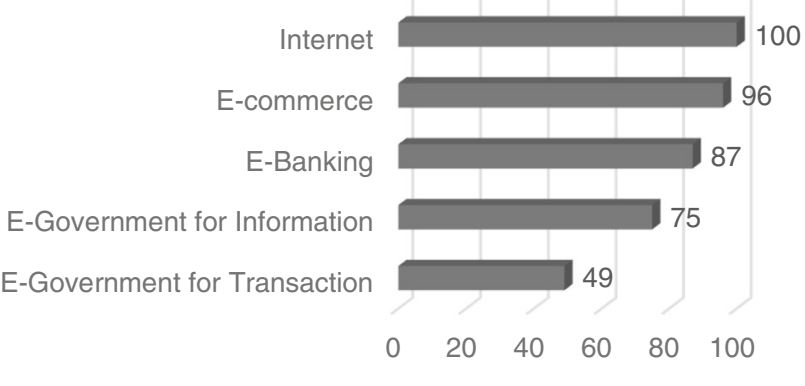

Fig. 3 Level of e-inclusion gaps in the UK

Respondents come from different employment, $40 \%$ of them are full time employees, $20 \%$ each for other categories.

The respondents indicate that the main reason for not using e-government is security concerns (See Fig. 4). Security concerns came first as the main reason for not using e-government service among respondents, lack of skills come second followed by high cost and finally lack of access. The results revealed that the main reasons that prevent people from using egovernment is security concern. This is related to trust in egovernment issue and consistent with the findings in the next section. The path from trust in e-government to attitude toward using e-government is significant. The second reason for not using e-government services is lack of skills. Moreover, the path from capacity to attitude toward using e-government was highly significant. This indicates the importance of skills. From the e-Inclusion gap model, it is clear that respondents are happy to adopt complex Internet activities that require skills, such as transaction services provided from business or banks. Moreover, using these Internet activities require trust in these activities as transactions are involved. A conclusion can be drawn from the findings that two main reasons for not using the e-government service are security concern and lack of skills. Moreover, people who are familiar with egovernment services and their benefits are more likely to use e-government (See Fig. 4).

The finding reveals that the path between trust in Internet and attitude toward using e-government is not significant while the path from trust in e-government and the attitude toward using e- government is significant. This indicates that one of the reasons that prevent participants from using egovernment services is trust in government.

\subsection{Descriptive Statistics}

Table 6 shows the Cronbach's alpha $(\alpha)$, mean, and standard deviation (S.D) for 25 constructs considered for e-Inclusion model. The number of items considered for all these constructs varies from a minimum of two to a maximum of six.

\subsection{Confirmatory Factor Analysis}

A confirmatory factor analysis using AMOS 20.0 was conducted to test the full measurement model. Seven common model-fit measures were used to assess the model's overall goodness of fit: the ratio of Chi square $(\chi 2)$ to degrees-offreedom (df), goodness-of-fit index (GFI), adjusted goodness-of-fit index (AGFI), Tucker-Lewis Index (TLI), Incremental Index of Fit (IFI), comparative fit index (CFI), and root mean square error of approximation (RMSEA). As shown in Table 7, all the model-fit indices exceeded their respective common acceptance levels suggested by previous research, thus demonstrating that the measurement model exhibited a fairly good fit with the data collected $(\chi 2=90.28$ with $\mathrm{df}=62, \mathrm{CMIN} / \mathrm{DF}=1.246, \mathrm{GFI}=0.980, \mathrm{AGFI}=0.961$, $\mathrm{IFI}=0.993, \mathrm{TLI}=0.989, \mathrm{CFI}=0.993, \mathrm{RMSEA}=0.040$ ).

From the above, the measurement model with all constructs showed a good fit for all indices. Table 8 shows path loadings,
Fig. 4 Reasons for citizens not using e-government in the UK

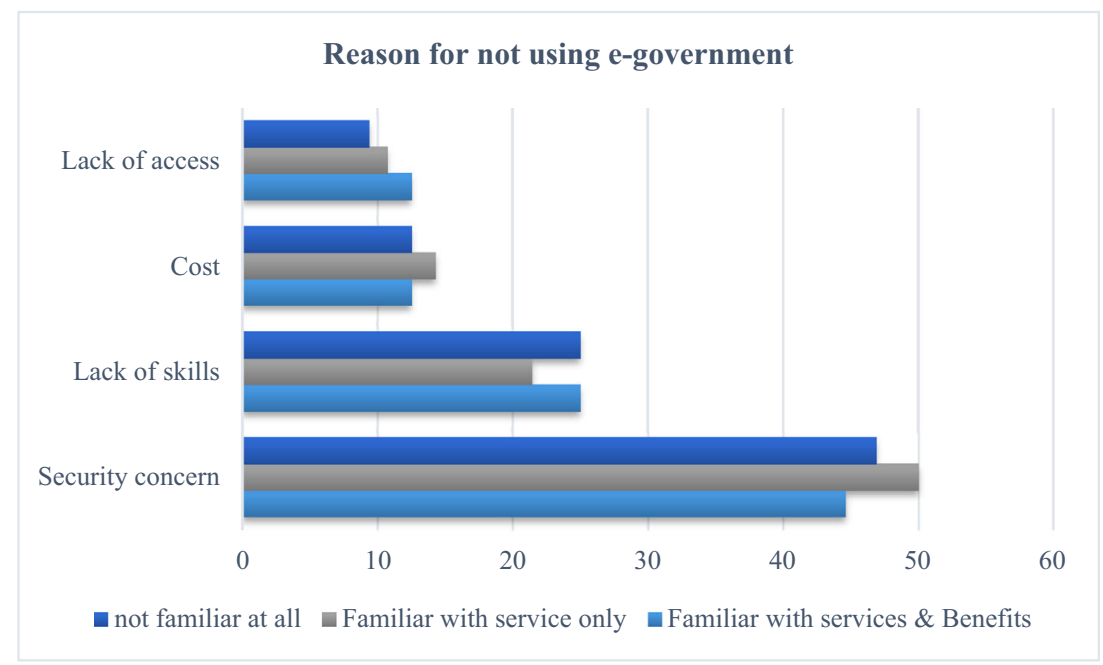


Table 6 Reliability of measurements

\begin{tabular}{|c|c|c|c|c|c|c|c|}
\hline \multicolumn{2}{|c|}{ Constructs } & \multirow{2}{*}{$\begin{array}{l}N \\
510\end{array}$} & \multirow{2}{*}{$\begin{array}{l}\text { \#Items } \\
4\end{array}$} & \multirow{2}{*}{$\begin{array}{l}\text { Mean } \\
5.38\end{array}$} & \multirow{2}{*}{$\begin{array}{l}\text { S.D } \\
1.007\end{array}$} & \multirow{2}{*}{$\begin{array}{l}(\alpha) \\
.883\end{array}$} & \multirow{2}{*}{$\begin{array}{l}\text { Type } \\
\text { High Reliability }\end{array}$} \\
\hline 1 & Perceived Ease of Use & & & & & & \\
\hline 2 & Perceived Usefulness & 510 & 3 & 5.11 & 1.126 & .895 & High Reliability \\
\hline 3 & Relative Advantage & 510 & 2 & 5.08 & 1.198 & .867 & High Reliability \\
\hline 4 & Compatibility & 510 & 3 & 4.84 & 1.104 & .927 & Excellent Reliability \\
\hline 5 & Accessibility & 510 & 3 & 5.57 & 1.206 & .879 & High Reliability \\
\hline 6 & Affordability & 510 & 3 & 5.24 & 1.146 & 839 & High Reliability \\
\hline 7 & Capacity & 510 & 3 & 5.45 & 1.084 & 837 & High Reliability \\
\hline 8 & Availability & 510 & 4 & 5.31 & 1.009 & .933 & Excellent Reliability \\
\hline 9 & Interpersonal Influence & 510 & 4 & 3.90 & 1.302 & 891 & High Reliability \\
\hline 10 & Government Influence & 510 & 2 & 4.50 & 1.397 & .920 & High Reliability \\
\hline 11 & Media Influence & 510 & 4 & 3.86 & 1.268 & .915 & Excellent Reliability \\
\hline 12 & Process Gratifications & 510 & 6 & 5.50 & .948 & .891 & High Reliability \\
\hline 13 & Content Gratifications & 510 & 5 & 5.58 & .969 & .890 & High Reliability \\
\hline 14 & Social Gratifications & 510 & 3 & 4.32 & 1.627 & .917 & Excellent Reliability \\
\hline 15 & Perceived Behaviour Control & 510 & 3 & 5.38 & 1.132 & .902 & Excellent Reliability \\
\hline 16 & Behavioural Intention & 510 & 3 & 4.92 & 1.327 & .944 & Excellent Reliability \\
\hline 17 & Attitude & 510 & 4 & 4.90 & 1.179 & .894 & High Reliability \\
\hline 18 & Use & 510 & 3 & 5.24 & .839 & .719 & High Reliability \\
\hline 19 & Subjective Norms & 510 & 3 & 4.04 & 1.280 & 894 & High Reliability \\
\hline 20 & Government Satisfaction & 360 & 6 & 5.16 & 1.045 & .933 & Excellent Reliability \\
\hline 21 & Internet Satisfaction & 510 & 8 & 5.91 & .869 & .822 & High Reliability \\
\hline 22 & Trust Government & 510 & 4 & 5.11 & 1.146 & 955 & Excellent Reliability \\
\hline 23 & Trust Internet & 510 & 3 & 5.01 & 1.136 & .925 & Excellent Reliability \\
\hline 24 & Perceived Trust & 510 & 5 & 4.70 & 1.077 & 916 & Excellent Reliability \\
\hline 25 & Perceived Risk & 510 & 3 & 4.47 & .959 & .779 & High Reliability \\
\hline
\end{tabular}

$N=$ Sample Size

critical ratios (C.R.), and R square values in the measurement model.

As a rule, the significant factor loading should not be less than 0.5 . The results indicate that all the standardised loading estimates are higher than 0.5 , with the lowest value equaling 0.667 . All the critical ratios ( $t$-value) were significant above the threshold of $\pm 1.96(p<0.001)$. The results also indicate that all the SMC are less than 0.90 , with the highest value equaling 0.869 . Once the model is specified and the fit indices indicate good fit, the construct validity should be assessed. Construct validity is assessed by convergent validity, and discriminant validity (Hair et al. 2006). Convergent validity means assigned indicators to measure certain factor are loading relatively high. Discriminant validity refers to the degree of distinctiveness between two constructs (Hair et al. 2006).

\subsubsection{Validity Assessment}

Validity is related with the accuracy of measures (Sekaran 2003). Validity is defined by Zikmund (2003) as "the ability of a scale to measure what it intended to be measured" (p.331). In other words, it determines the extent to which a construct and its corresponding measurement indicators are related, and the extent to which these set of items actually reflect the construct they were designed to measure (Hair et al. 2006). According to Neuman (2006), the better the fit between theoretical latent construct and measured items, the greater establishment of validity. Assessing the construct validity is one of the main objectives of using CFA (Hair et al. 2006). Construct validity can be examined by assessing the convergent validity and the discriminant validity which are explained as follows.

Convergent Validity The convergent validity means the indicators measuring certain construct share the high proportion of variance in common (Hair et al. 2006). For this study, convergent validity was assessed by examining: 1) factor loadings, which relate significantly all indicators to their respective constructs; all the absolute values of critical ratios (C.R.) of all the indicators should be greater than 1.96, at the 0.05 level of significance, 2) standardized regression coefficients, which should be greater than 0.50 , and 3 ) the average variance extracted (AVE), which reflects the overall amount of variance in the indicators accounted for by the latent construct. Thus,
Table 7 Overall fit indices of measurement model with all constructs

\begin{tabular}{llllllll}
\hline Model & RMSEA & $\begin{array}{l}\text { CMIN/ } \\
\text { DF }\end{array}$ & GFI & AGFI & CFI & TLI & IFI \\
\hline Default model & .040 & 1.246 & .980 & .961 & .993 & .989 & .993 \\
Recommend criteria & $<.080$ & $>3$ & $\geq 0.90$ & $\geq 0.80$ & $\geq 0.90$ & $\geq 0.90$ & $\geq 0.90$ \\
\hline
\end{tabular}


higher values of the AVE indicate that the items are truly representative of the latent construct. An average variance extracted (AVE) of at least 0.50 provides support for convergent validity. The rule of thumb indicates that good AVE starts from the value of 0.5 (Hair et al. 2016). As a rule, for factor loading, the significant factor should not be less than 0.5 . The results indicate that all the standardised loading estimates are higher than 0.5 , with the lowest value equalling 0.627 . All the critical ratios ( $t$-value) were significant above the threshold of \pm 1.96 ( $p<0.001)$. Table 8 presents summary results of convergent validity.

The standardised factor loading was above the minimum of 0.5 , with significant t-values. Also, the average variance extracted was above 0.5 for all constructs, suggesting good convergence. The reliability of the constructs was above 0.7 , ranging from 0.712 to 0.924 , indicating good reliability.

Discriminant Validity The discriminant validity was introduced by Hair et al. (2006: p. 771) as "the extent to which a construct is truly distinct from other construct". For this study, discriminant validity was assessed by comparing the squared correlation between two constructs with their respective average variance extracted (AVE). The average variance extracted (AVE) of both constructs should be greater than the squared correlation between the two constructs. Discriminant validity can be assessed using a
Table 8 Summary results of convergent validity

\begin{tabular}{|c|c|c|c|}
\hline Construct & Factor loading & $\begin{array}{l}\text { Construct reliability } \\
\text { (CR) }\end{array}$ & $\begin{array}{l}\text { Average variance } \\
\text { extracted (AVE) }\end{array}$ \\
\hline \multicolumn{4}{|l|}{ Continuity } \\
\hline IS6 & .785 & \multirow[t]{3}{*}{.746} & \multirow[t]{3}{*}{.921} \\
\hline IS7 & .667 & & \\
\hline IS8 & .787 & & \\
\hline \multicolumn{4}{|l|}{ Satisfaction } \\
\hline IS1 & .840 & \multirow[t]{8}{*}{.800} & \multirow[t]{8}{*}{.928} \\
\hline IS2 & .842 & & \\
\hline IS3 & .843 & & \\
\hline IS4 & .708 & & \\
\hline IS5 & .932 & & \\
\hline IS6 & .785 & & \\
\hline IS7 & .667 & & \\
\hline IS8 & .787 & & \\
\hline \multicolumn{4}{|l|}{ Use } \\
\hline USE1 & .685 & \multirow[t]{3}{*}{.712} & \multirow[t]{3}{*}{.755} \\
\hline USE2 & .774 & & \\
\hline USE3 & .677 & & \\
\hline \multicolumn{4}{|c|}{ Behavioural Intention } \\
\hline BI1 & .839 & \multirow[t]{4}{*}{.895} & \multirow[t]{4}{*}{.949} \\
\hline BI2 & .940 & & \\
\hline $\mathrm{BI} 3$ & .951 & & \\
\hline BI4 & .851 & & \\
\hline \multicolumn{4}{|c|}{ Process Gratifications } \\
\hline PG1 & .775 & \multirow[t]{6}{*}{.748} & \multirow[t]{6}{*}{.868} \\
\hline PG2 & .812 & & \\
\hline PG3 & .821 & & \\
\hline PG4 & .627 & & \\
\hline PG5 & .686 & & \\
\hline PG6 & .766 & & \\
\hline \multicolumn{4}{|c|}{ Content Gratifications } \\
\hline CG1 & .664 & \multirow[t]{5}{*}{.784} & \multirow[t]{5}{*}{.911} \\
\hline CG2 & .914 & & \\
\hline CG3 & .894 & & \\
\hline CG4 & .657 & & \\
\hline CG5 & .791 & & \\
\hline \multicolumn{4}{|c|}{ Social Gratifications } \\
\hline SG1 & .826 & \multirow[t]{3}{*}{.841} & \multirow[t]{3}{*}{.920} \\
\hline SG2 & .861 & & \\
\hline SG3 & .836 & & \\
\hline Attitude & & & \\
\hline ATT1 & .867 & .827 & .899 \\
\hline ATT2 & .908 & & \\
\hline ATT3 & .801 & & \\
\hline ATT4 & .730 & & \\
\hline Subjective & & & \\
\hline SN1 & .733 & .861 & .926 \\
\hline SN2 & .914 & & \\
\hline SN3 & .937 & & \\
\hline Perceived I & trol & & \\
\hline PBC1 & .902 & .867 & .901 \\
\hline $\mathrm{PBC} 2$ & .871 & & \\
\hline $\mathrm{PBC} 3$ & .828 & & \\
\hline
\end{tabular}


Table 8 (continued)

\begin{tabular}{|c|c|c|c|}
\hline Construct & Factor loading & $\begin{array}{l}\text { Construct reliability } \\
\text { (CR) }\end{array}$ & $\begin{array}{l}\text { Average variance } \\
\text { extracted (AVE) }\end{array}$ \\
\hline \multicolumn{4}{|c|}{ Accessibility } \\
\hline $\mathrm{ACC} 1$ & .833 & \multirow[t]{3}{*}{.845} & \multirow[t]{3}{*}{.822} \\
\hline ACC2 & .807 & & \\
\hline ACC3 & .895 & & \\
\hline \multicolumn{4}{|c|}{ Affordability } \\
\hline AFF1 & .835 & \multirow[t]{2}{*}{.854} & \\
\hline AFF2 & .872 & & \\
\hline \multicolumn{4}{|l|}{ Capacity } \\
\hline CAP1 & .867 & \multirow[t]{4}{*}{.878} & \multirow[t]{4}{*}{.939} \\
\hline CAP2 & .923 & & \\
\hline CAP3 & .902 & & \\
\hline CAP5 & .818 & & \\
\hline \multicolumn{4}{|l|}{ Availability } \\
\hline AV2 & .690 & \multirow[t]{3}{*}{.804} & \multirow[t]{3}{*}{.862} \\
\hline AV3 & .908 & & \\
\hline AV4 & .813 & & \\
\hline \multicolumn{4}{|c|}{ Perceive Ease of Use } \\
\hline PEOU1 & .765 & \multirow[t]{4}{*}{.822} & \multirow[t]{4}{*}{.892} \\
\hline PEOU2 & .843 & & \\
\hline PEOU3 & .875 & & \\
\hline PEOU4 & .805 & & \\
\hline \multicolumn{4}{|c|}{ Perceived Usefulness } \\
\hline PU1 & .843 & \multirow[t]{3}{*}{.880} & \multirow[t]{3}{*}{.939} \\
\hline PU2 & .858 & & \\
\hline PU3 & .938 & & \\
\hline \multicolumn{4}{|c|}{ Compatibility } \\
\hline COMP1 & .896 & \multirow[t]{3}{*}{.901} & \multirow[t]{3}{*}{.821} \\
\hline COMP2 & .920 & & \\
\hline COM3 & .886 & & \\
\hline Interpersona & & & \\
\hline II1 & .861 & .857 & .898 \\
\hline II2 & .868 & & \\
\hline II3 & .841 & & \\
\hline Media Influ & & & \\
\hline EI1 & .869 & .864 & .899 \\
\hline EI2 & .891 & & \\
\hline EI3 & .833 & & \\
\hline Governmen & & & \\
\hline EI5 & .966 & .924 & \\
\hline EI6 & .882 & & \\
\hline Trust in Go & & & \\
\hline TG1 & .846 & .884 & .920 \\
\hline TG2 & .890 & & \\
\hline TG4 & .917 & & \\
\hline Trust in Inte & & & \\
\hline PT1 & .689 & .793 & .900 \\
\hline PT3 & .909 & & \\
\hline PT4 & .713 & & \\
\hline PT5 & .862 & & \\
\hline Perceived R & & & \\
\hline PR1 & .637 & .737 & .782 \\
\hline PR2 & .796 & & \\
\hline PR3 & .777 & & \\
\hline
\end{tabular}

rigorous test by comparing the average variance extracted values for any two constructs with the square of the correlation estimate between these two constructs. The rule that verifies discriminant validity is: AVE $>$ squared correlation estimate. Therefore, the AVE calculated will be compared with the square of the correlation estimate between constructs, as depicted in Table 9. The results of the Table 7 support the existence of discriminant validity between constructs since the AVE between any two constructs is greater than the squared correlation estimate. In summary, the measurement model demonstrated adequate reliability, convergent validity, and discriminant validity.

\subsection{Structural Model and Hypotheses Testing}

In order to test the relationships between constructs as hypothesised in the proposed theory, the measurement model is transformed to a structural model by assigning the relationships between constructs based on theory (Hair et al. 2006). The hypotheses are represented by the specified relationships among constructs. The structural model moves from the stage of specifying the relationship between the latent constructs and measured variables in the measurement model to an advanced level; at which the nature and strength of the relationships between constructs are determined (Hair et al. 2006). In 


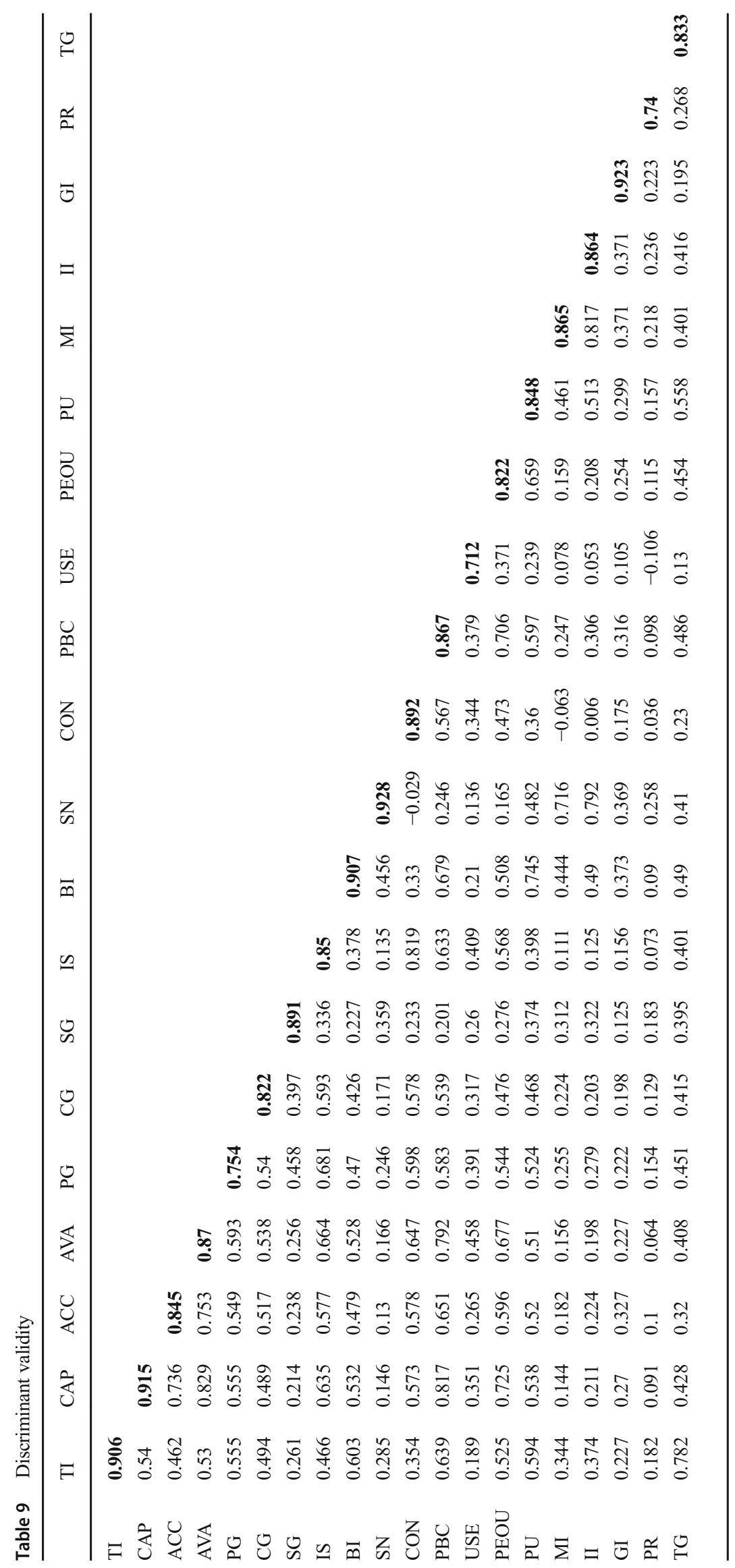


other words, it moves from using CFA to the use of SEM to test the hypotheses.

The first step in model testing is to estimate the goodnessof-fit of the research model. The similar set of fit indices used to examine the measurement model will be used to examine the structural model: the ratio of Chi square $\left(\chi^{2}\right)$ to degreesof-freedom (df), (GFI), (AGFI), (TLI), (IFI), (CFI), and (RMSEA). All of the fit indexes indicate that the structural model has a good fit: Chi-square/d.f. $(\leqq 3.0)=2.086$, GFI $(\geqq 0.90)=0.900$, AGFI $(\geqq 0.80)=0.800$, IFI $(\geqq 0.90)=0.932$, TLI $(\geqq 0.90)=0.925$, RMSEA $(\leqq 0.08)=0.046$, CFI $(\geqq 0.90)=0.931$.

The second step in model estimation is to examine the path significance of each hypothesized association in the research model and variance explained $\left(\mathbf{R}^{\mathbf{2}}\right)$ by each path. The parameter estimates were used to produce the estimated population covariance matrix for the structural model. The model was defined by 77 measurement items that identified the eleven latent constructs. The covariance matrix among the constructs was applied to test the model. When the critical ratios (CRs or t-value) is higher than 1.96 for an estimate (regression weight), then the parameter coefficient value is statistically significant at the .05 levels (Hair et al. 2006). Critical ratios or t-value was obtained by dividing the regression weight estimate by the estimate of its standard error (S.E). Using the path estimates and CRs values, thirty causal paths were examined in this study. For 24 causal path estimates t-values were above the 1.96 critical values at $(p \leq .05)$. The $t$-values for remaining six constructs were found statically not significant. The overall structural model is depicted in Fig. 5, and parameter estimates are presented in Table 10. It is to be noted that the measurement items and error terms associated with latent constructs are not shown for clarity.

Results presented in Table 10 indicate that the twenty four of 30 hypothesized paths between independent and dependent variables were significant. For instance, the hypothesised path between perceived ease of use and perceived usefulness with CR value of 14.885 ( $>1.96$ ) was statistically significant ( $p=$ 0.001 ). Similarly, paths between perceived usefulness and attitude; perceived ease of use and attitude; trust government and attitude; perceived risk and trust government; capacity and perceived behavioural control; availability and perceived behavioural control; interpersonal influence and subjective norm; attitude and behaviour intention; perceived behavioural control and behaviour intention; subjective norm and behaviour intention; social gratification and continuity; satisfaction and continuity; process gratification and continuity were statistically significant at $(\mathrm{p}=0.001)$. The hypothesized paths between accessibility and use; media influence and subjective norm; content gratification and satisfaction; process gratification and use; process gratification and satisfaction; behaviour intention and use; use and satisfaction; use and continuity; content gratification and continuity were statistically significant at $p=<.05$. The hypothesized paths between perceived risk and attitude; trust internet and attitude; accessibility and perceived behaviour control; content gratification and use; social gratification and use indicated that their t-values did not exceed the cut-off point required for statistical significance. Thus, these paths were not statistically significant. Figure 5 presents path coefficient for the structural model.

\section{Discussion and Reflection}

Two decades of digital divide research reveal that access is associated with age (Loges and Jung 2001), gender (Wasserman and Richmond-Abbott 2005; Wilson et al. 2003), education (Bucy 2000), income (Rice and Haythornthwaite 2006), ethnicity (Hoffman et al. 1999; Carter et al. 2016), and geography (Hindman 2000; Wei and Zhang 2008; Mahmood et al. 2018). This was a legitimate focus of inquiry in the early phases of Internet diffusion and contributed to our understanding of digital inclusion research. The empirical findings in this study are consistent with the literature and confirm the variations in demographic profile when it comes to use of e-government services in the UK.

Using the study of Becker et al. (2008) as the basis, the empirical data collected in the UK was analysed to identify e-inclusion gaps. The first gap is the gap between Internet use (Total respondents) and e-commerce use, $4 \%$ of the respondents who are already Internet users have never shopped online. The second gap is between Internet users and the e-commerce users, while $83 \%$ of the total population have used the Internet only $60 \%$ of the population have used it for buying or ordering goods. The individuals in this gap fulfil the elementary requirement of having access to the internet; however, they do not engage in transactions. The third gap is between the e-commerce users and the egovernment users; while $60 \%$ of the population used ecommerce only $40 \%$ of them have used it for egovernment services. People in this gap are performing transactions using the internet. Therefore, they have the qualification necessary to engage in more complex actions and have no trust issues with the internet. However, they do not participate in e-government at all. This gap could be explained through a general preference for personal contact when performing government transactions or missing knowledge about the available e-government information and services. In common models of e-government service development the provision of information is the first step when deploying e-government services. Accordingly, the retrieval of this information is the first step in using egovernment services while transactional activities are seen as full engagement; the latter was visibly limited based on our empirical findings. 
Fig. 5 Path coefficient for structural model

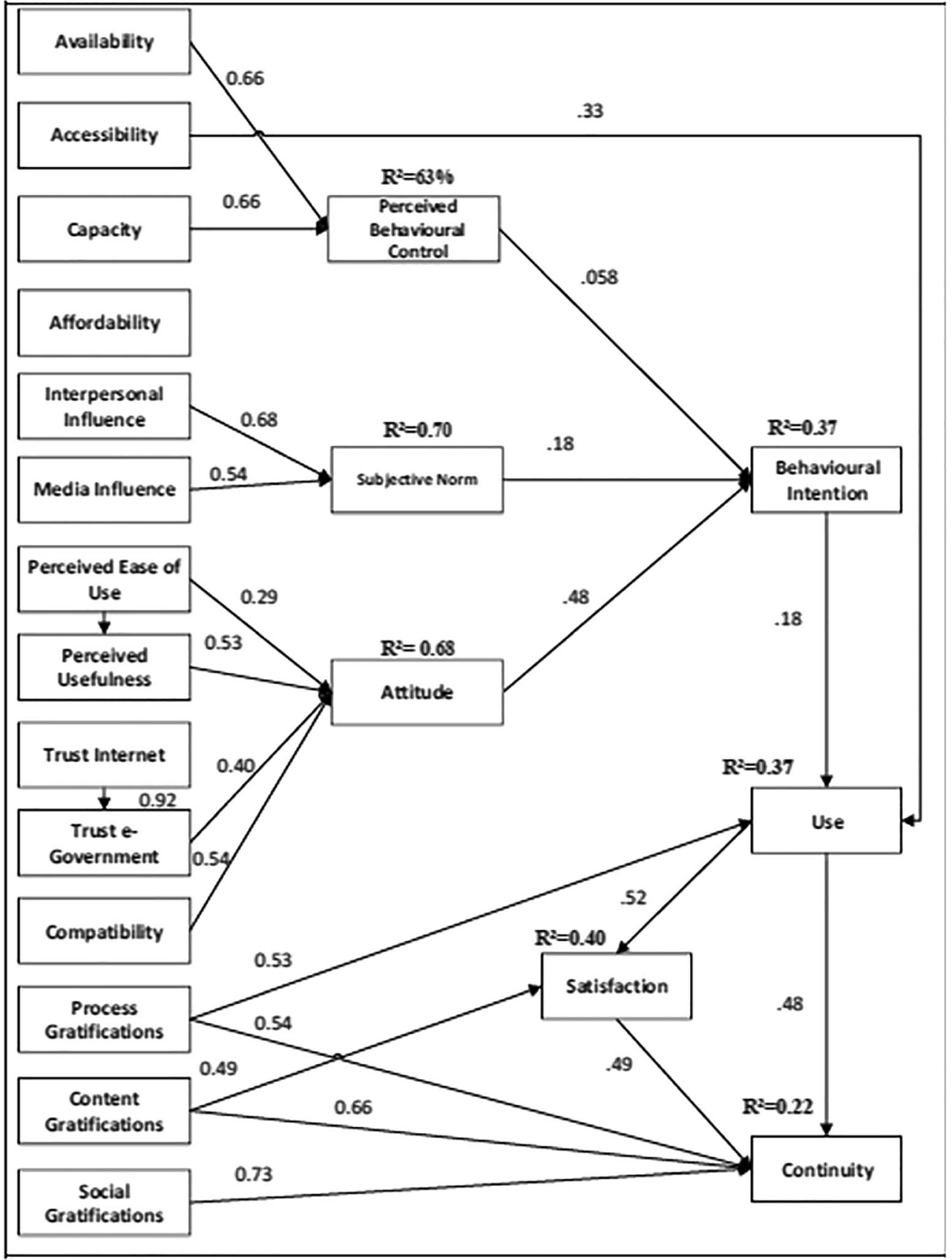

\subsection{Implications to Literature}

A review of literature found that the lack of conceptual definitions and theoretical frameworks for e-Inclusion has prevented the development of reliable measurement and identification of specific factors that influence e-Inclusion. To this end, it is hoped that the developed taxonomy in this study offers greater elaboration and refinement of the variables that can be used to assess e-Inclusion and will thus contribute towards addressing these gaps in the literature and current eInclusion research. In order to assist selection of an appropriate model and constructs for current research, the theories that are used in e-government adoption and e-Inclusion research were discussed with their focus, description and limitations. Based on this, a research model was developed to capture and examine the e-Inclusion factors that influence citizens' use of e-government services based on the Decomposed Theory of Planned Behaviour (DTPB) and Uses and Gratifications Theory (U\&G). Although successive governments have introduced league tables and other evaluation methods to identify and support good practice, the measures and methods used have often been subjective. In this context, this research used established theoretical norms to develop a conceptual basis and applied this in practice to better understand the various 
Table 10 Path loadings and critical ratios within constructs in the structural model

\begin{tabular}{|c|c|c|c|c|c|}
\hline \multicolumn{2}{|l|}{ Hypothesis } & \multirow{2}{*}{$\begin{array}{l}\text { Standard error (SE) } \\
.044\end{array}$} & \multirow{2}{*}{$\begin{array}{l}\text { Critical ratios } \\
5.512\end{array}$} & \multirow{2}{*}{$\begin{array}{l}P \text { value } \\
* * * *\end{array}$} & \multirow{2}{*}{$\begin{array}{l}\text { Finding } \\
\text { Supported }\end{array}$} \\
\hline H1 & Perceived usefulness $\rightarrow$ attitude & & & & \\
\hline $\mathrm{H} 2$ & Perceived ease of use $\rightarrow$ attitude & .050 & 5.601 & $* * *$ & Supported \\
\hline $\mathrm{H} 3$ & Perceived ease of use $\rightarrow$ perceived usefulness & .051 & 14.885 & $* * *$ & Supported \\
\hline $\mathrm{H} 4$ & Trust government $\rightarrow$ attitude & .032 & 3.379 & $* * *$ & Supported \\
\hline H5a & Perceived risk $\rightarrow$ attitude & .034 & 1.123 & .262 & Rejected \\
\hline $\mathrm{H} 5 \mathrm{~b}$ & Perceived risk $\rightarrow$ trust e-government & .070 & 4.174 & $* * *$ & Supported \\
\hline H6a & Trust Internet $\rightarrow$ Trust e-government & .050 & 20.955 & $* * *$ & Supported \\
\hline $\mathrm{H} 6 \mathrm{~b}$ & Trust Internet $\rightarrow$ attitude & .093 & .760 & .447 & Rejected \\
\hline $\mathrm{H} 7 \mathrm{a}$ & Accessibility $\rightarrow$ perceived behaviour control & .060 & 1.271 & .204 & Rejected \\
\hline $\mathrm{H} 7 \mathrm{~b}$ & Accessibility $\rightarrow$ Use & .042 & 2.426 & .015 & Supported \\
\hline H8 & Capacity $\rightarrow$ perceived behaviour control & .083 & 4.617 & $* * *$ & Supported \\
\hline H9 & Availability $\rightarrow$ perceived behaviour control & .144 & 4.056 & $* * *$ & Supported \\
\hline H10 & Media influence $\rightarrow$ subjective norms & .074 & 2.321 & .020 & Supported \\
\hline H11 & Interpersonal influence $\rightarrow$ subjective norms & .083 & 8.903 & $* * *$ & Supported \\
\hline H12 & Attitude $\rightarrow$ behaviour intention & .082 & 8.265 & $* * *$ & Supported \\
\hline H13 & Perceived behavioural control $\rightarrow$ behaviour intention & .097 & 5.682 & $* * *$ & Supported \\
\hline H14 & Subjective norms $\rightarrow$ behaviour intention & .036 & 4.929 & $* * *$ & Supported \\
\hline H15a & Content gratifications $\rightarrow$ Use & 0.29 & 1.697 & .090 & Rejected \\
\hline $\mathrm{H} 15 \mathrm{~b}$ & Content gratifications $\rightarrow$ Satisfaction & .044 & 3.282 & .001 & Supported \\
\hline $\mathrm{H} 15 \mathrm{c}$ & Content gratifications $\rightarrow$ Continuity & 1.223 & 2.874 & .004 & Supported \\
\hline H16a & Process gratifications $\rightarrow$ Use & .957 & 2.179 & .029 & Supported \\
\hline $\mathrm{H} 16 \mathrm{~b}$ & Process gratifications $\rightarrow$ Satisfaction & .643 & 2.996 & .003 & Supported \\
\hline H16c & Process gratifications $\rightarrow$ Continuity & 1.256 & 3.889 & $* * *$ & Supported \\
\hline $\mathrm{H} 17 \mathrm{a}$ & Social gratifications $\rightarrow$ Use & 0.28 & 1.592 & .111 & Rejected \\
\hline $\mathrm{H} 17 \mathrm{~b}$ & Social gratifications $\rightarrow$ Satisfaction & .027 & .612 & .540 & Rejected \\
\hline $\mathrm{H} 17 \mathrm{c}$ & Social gratifications $\rightarrow$ Continuity & .022 & 3.309 & $* * *$ & Supported \\
\hline H18 & Behaviour intention $\rightarrow$ Use & .036 & 2.919 & .004 & Supported \\
\hline H19a & Use $\rightarrow$ Satisfaction & .076 & 2.652 & .008 & Supported \\
\hline $\mathrm{H} 19 \mathrm{~b}$ & Use $\rightarrow$ Continuity & .076 & 3.053 & .002 & Supported \\
\hline $\mathrm{H} 20$ & Satisfaction $\rightarrow$ Continuity & .069 & 6.592 & $* * *$ & Supported \\
\hline
\end{tabular}

*Significance at the 0.05 level

**Significance at the 0.01 level and

*** Significance at the 0.001 level

dimensions of e-inclusion. Six dimensions were identified as key inhibitors for e-Inclusion in the UK namely: demographical, economic, social, cultural, political, and infrastructural.

This study posits that identifying the reasons which prevent people from using e-government will help to enhance our understanding of the critical factors that influence eInclusion and why people keep using other Internet activities that required qualification and trust to engage in advanced online activities (such as e-commerce) but they do not use egovernment services.

\subsection{Implications to Policy and Practice}

For practitioners, particularly policymakers, this study has important implications especially when E-inclusion has become a prerequisite for policy initiatives and actions carried out by European Member States. The findings here challenge assumptions guiding typical ICT policy formulation that technology access and infrastructure facilities alone are enough and provide actionable recommendations for addressing e-inclusion. They suggest that policymakers should acknowledge the complexity and dynamics of the phenomenon and look at
e-Inclusion well beyond the technology access issues to recognize key aspects of behaviour that characterize potential adopters and not-adopters and design policy interventions to address identified gaps.

From our research findings, it can be argued that the UK government does not have influence on citizens' decision to use e-government services and $76 \%$ of non- e-government users are not familiar with the services provided by the government and the benefits from using these services. Trust in the Internet as a medium is not an issue anymore, while trust in e-government plays a role on citizens decision to use e-government. In this context, the results offer policy makers and practitioners a better overview of the broader dimensions of eInclusion as well as the most critical factors that prevent people from being part of the digital-by-default environment in the UK (e.g. trust in e-government, process gratifications, perceived ease of use, media influence, interpersonal influence, and capacity). To ensure citizens use e-government, it is important to give attention to the process gratifications to ensure satisfaction of citizens and attention should be given to the content gratifications; and to ensure continuity of use, both content and social gratifications should be given attention. 
Finally, from an infrastructural dimension, it is imperative for policy makers to ensure the availability and affordability of egovernment services by utilizing multiple channels (e.g., mobile phones, televisions, kiosks) including face-to-face interaction to accommodate the diverse needs of citizens. It is hoped that these findings will offer policy makers and practitioners insights into e-inclusion that will allow them to meet both users and non-users' needs when faced with the task of deciding the delivery of e-government services to their communities.

Policies and initiatives that take digital-by-default as a starting point are in danger of ignoring the complexity of the field. Worse, they lead to a real danger that a large part of the population will become digitally excluded by default. In this respect, aspects of inclusion other than infrastructure and skills should be built into digital inclusion policies. UK digital policy previously (late 1990s to early 2000s) involved much more government involvement. It included policies and initiatives geared towards guaranteeing infrastructure for all and improving opportunities for digital participation. Key policies and research were situated within several government departments (e.g. The Cabinet Office, BIS, and the regulator Ofcom). Currently, the most obvious involvement from government is in promoting superfast broadband and 4G (and experimenting with $5 \mathrm{G}$ testbeds) on the existing and new infrastructures through the Department of Culture, Media and Sport and acquisition of employment related digital skills through the Department of Business, Innovations and Skills. This means policy has been situated outside the social, educational, cultural and political sphere and is therefore not able to address the motivational and socio-cultural factors that so strongly predict engagement with ICTs. In this context, the findings in this study should motivate policy makers to take into consideration the alignment of e-government initiatives with e-inclusion policies that encapsulate individual and behavioural needs. If not, policies and initiatives that take digital by default as a starting point are in danger of ignoring the complexity of the field. Worse, they lead to a real danger that a large part of the population will become digitally excluded by default.

\section{Conclusion}

Despite the large investments in digital inclusion policies, including The Digital-by-Default in the UK, the impact of electronic services is yet to be systematically evaluated. From the empirical quantitative work undertaken in the UK to verity the main identified dimensions for this study, it can be posited that although successive governments have introduced league tables and other evaluation methods to identify and support good practice, the measures and methods used have often been subjective. In this context, this research used established theoretical norms to develop a conceptual basis and applied this in practice to better understand the various dimensions of e-inclusion. Through analysing the Internet activities use in the UK and identifying existence gaps in e-government use by the citizens in the UK, four gaps were found. The use of egovernment was the deepest gap that exists in the Internet activities used by the citizens. The authors suggest that finding out the factors that prevent people from using e-government will help to enhance our understanding of the critical factors that influence e-Inclusion and why people keep using other Internet activities that required qualification and trust to engage in advance online actions, but not e-government services.

\subsection{Research Limitations and Future Focus}

Although the findings of this study are encouraging and useful, the authors acknowledge that this research has limitations, and therefore the conclusions drawn should be interpreted as such. The empirical conclusions in this study are drawn from a sample of 510 surveys in the UK. Nevertheless, the research approach taken was purposeful for this study, as the key empirical objective was to evaluate the conceptual taxonomy and associated factors among a sample of citizens who were knowledgeable with ICT and e-government services, and to explain the adoption gaps in using different Internet activities by citizens, specifically the gap between using e-government services and other Internet activities. Moreover, the demographic analysis indicates that the above e-Inclusion criteria are realistically covered within the survey sample used.

A future research can consider probability sampling for collecting the data, which suggests that every unit in the population will have some probability (non-zero probability) of being selected in the sample (Bhattacherjee 2000). It can also examine the impacts of independent variables such as accessibility, Interpersonal influence, facilitating conditions, trust in e-government and perceived risk under the moderating effects on age, gender, experience, education, and income. Prior research (e.g Wang and Shih 2008) on e-government has also shown that moderating variables might provide the differences on the relationships between the determinants and intention to use Internet activities (e.g. e-government, e-banking, and e-shopping). The data for this research should be collected from more diversified geographical locations to make the research outcome truly generalizable as far as the sample of this research is concerned. Most studies on uses and gratifications have been quantitative (Ruggiero 2000), Internet research being no exception (Grace-Farfaglia et al. 2006). Future research should focus on composing a suitable set of gratifications (for e-adoption domains in particular) through qualitative research which include in depth interviews. This will overcome the limited information available about the gratifications of new media such as e-government (Ruggiero 
2000; Stafford et al. 2004). It will be interesting to test and explore the model developed for this study in other national settings across Europe and elsewhere. This will be valuable in providing evidence concerning the robustness of the research model across different settings.

Open Access This article is distributed under the terms of the Creative Commons Attribution 4.0 International License (http:// creativecommons.org/licenses/by/4.0/), which permits unrestricted use, distribution, and reproduction in any medium, provided you give appropriate credit to the original author(s) and the source, provide a link to the Creative Commons license, and indicate if changes were made.

\section{References}

Ajzen, I. (1985). From intentions to actions: A theory of planned behavior. Springer.

Ajzen, I. (1988). Attitudes, personality, and behavior. Chicago: Dorsey.

Ajzen, I. (1991). The theory of planned behavior. Organizational Behavior and Human Decision Processes, 50(2), 179-211.

Ajzen, I., \& Fishbein, M. (1980). Understanding attitudes and predicting social behaviour. Englewood Cliffs: Prentice-Hall.

Ajzen, I., \& Madden, T. J. (1986). Prediction of goal-directed behavior: Attitudes, intentions, and perceived behavioral control. Journal of Experimental Social Psychology, 22(5), 453-474.

Almuwil, A., Weerakkody, V. and El-Haddadeh, R. (2011). 'A conceptual study of the factors influencing E-inclusion', European, Mediterranean and Middle Eastern Conference on Information Systems, (EMCIS 2011), Athens, Greece.

Bandura, A. (1986). Social foundations of thought and action: A social cognitive theory. Englewood Cliffs: Prentice-Hall.

Becker, J., Niehaves, B. and Bergener, P. (2008). 'Digital Divide in e Government: The eInclusion Gap Model' in Electronic Government. 7th International Conference, EGOV 2008, Turin, Italy, august 31-September 5, 2008. Proceedings Springer Berlin / Heidelberg.

Bélanger, F., \& Carter, L. (2008). Trust and risk in E-Government adoption. Journal of Strategic Information Systems, 17, 165-176.

Benbasat, I., \& Zmud, R. W. (1999). Empirical research in information systems: The practice of relevance. MIS Quarterly, 23, 3-16.

Bentivegna, S., \& Guerrieri, P. (2010). Analysis of e-inclusion impact resulting from advanced $\mathrm{R} \& \mathrm{D}$ based on economic modeling relation to innovation capacity, capital formation, productivity, and empowerment. A Composite Index to measure digital Inclusion in Europe. Brussel: European Commission.

Bhattacherjee, A. (2000). Acceptance of e-commerce services: The case of electronic brokerages. IEEE Transactions on Systems, Man, and Cybernetics - Part A: Systems and Humans, 30(4), 411-420.

Bradbrook, G. and Fisher, J. (2004). 'Digital equality: Reviewing digital inclusion activity and mapping the way forwards', Citizens online.

Bruno, G., Esposito, E., Genovese, A., \& Gwebu, K. L. (2010). A critical analysis of current indexes for digital divide measurement. The Information Society, 27(1), 16-28.

Bryman, A., \& Bell, E. (2011). Business Research Methods (3rd ed.). New York: Oxford University Press.

Bucy, E. P. (2000). Social access to the internet. Harvard International Journal of Press-Politics, 5(1), 50-61.

Cabinet Office (2012), Government Digital Strategy, Published 6 November 2012, Available at: https://www.gov.uk/government/ publications/government-digital-strategy, last accessed on 27/12/ 2018.

Carter, L., Weerakkody, V., Phillips; B. and Dwivedi, Y.D. (2016), Citizen adoption of E-government services: Exploring citizen perceptions of online services in the US and UK, Information Systems Management, 33(2), 124-140.

Chau, P. Y., \& Hu, P. J. (2001). Information technology acceptance by individual professionals: A model comparison approach. Decision Sciences, 32(4), 699-719.

Chen, Q., \& Wells, W. (1999). Attitude toward the site. Journal of Advertising Research, 39(5), 27-38.

Chu, P., Hsiao, N., Lee, F., \& Chen, C. (2004). Exploring success factors for Taiwan's government electronic tendering system: behavioral perspectives from end users. Government Information Quarterly, 21(2), 219-234.

Codagnone, C. (2009). 'Vienna study on inclusive innovation for growth and cohesion: Modelling and demonstrating the impact of eInclusion', European Commission.

Comrey, A., \& Lee, H. (1992). A first course in factor analysis. Hillsdale: Lawrence Erlbaum Associates.

Cornford, T., \& Smithson, S. (2006). Project research in information systems: a student's guide. Palgrave.

Creswell, J. W. (2008). Research design: Qualitative, quantitative, and mixed methods approaches. Thousand Oaks: Sage.

Cruz-Jesus, F., Oliveira, T., \& Bacao, F. (2017). Assessing the pattern between economic and digital development of countries. Information Systems Frontiers, 19(4), 835-854.

Cullen J., Hadjivassiliou K. and Junge K. (2007). Status of eInclusion measurement, analysis and approaches for improvement. Available at: http://www.icele.org/downloads/e inclusion handbook final submitted_0307.pdf (accessed: 02/28 2018).

Cutler, N. E., \& Danowski, J. A. (1980). Process gratification in aging cohorts. Journalism Quarterly, 57(2), 269-276.

Damarin, S. K. (2000). The 'digital divide' versus digital differences: Principles of equitable use of technology in education. Educational Technology, 40, 17-22.

Davis, F. D. (1989). Perceived usefulness, perceived ease of use, and user acceptance of information technology. MIS Quarterly, 13(3), 319339.

Davis, F. D., Bagozzi, R. P., \& Warshaw, P. R. (1989). User acceptance of computer technology: A comparison of two theoretical models. Management Science, 35(8), 982-1003.

Diddi, A., \& LaRose, R. (2006). Getting hooked on news: Uses and gratifications and the formation of news habits among college students in an internet environment. Journal of Broadcasting and Electronic Media, 50(2), 193-210.

Dijk, J.v. (2005). The deepening divide: inequality in the information society. Thousand Oaks: Sage Publications.

DiMaggio, P. and Hargittai, E. (2001). From the 'Digital Divide to Digital Inequality': Studying internet use as penetration increases. Princeton Center for Arts and Cultural Policy Studies, working paper series number 15 .

E-Government Fact Sheet (2018), E-Government in the UK, European Commission, Available at: https://joinup.ec.europa.eu/sites/default/ files/inline-files/eGovernment_in_United_Kingdom_2018_0.pdf , Last accessed on 29/12/2018.

Eighmey, J., \& McCord, L. (1998). Adding value in the information age: Uses and gratifications of sites on the world wide web. Journal of Business Research, 41(3), 187-194.

El-Haddadeh, R., Weerakkody, V., Osmani, M., Thakker, D., \& Kapoor, K. (2019). Examining citizens' perceived value of internet of things Technologies in Facilitating Public Sector Services Engagement. Government Information Quarterly, 36, 310-320. https://doi.org/ 10.1016/j.giq.2018.09.009. 
Featherman, M. S., \& Pavlou, P. A. (2003). Predicting E-Services adoption: A perceived risk facets perspective. International Journal of Human-Computer Studies, 59, 451-474.

Fishbein, M. and Ajzen, I. (1975) Belief, attitude, intention and behavior: An introduction to theory and research. Reading, MA: AddisonWesley.

Fuchs, C. (2009). The role of income inequality in a multivariate crossnational analysis of the digital divide. Social Science Computer Review, 27(1), 41-58.

GDS (2015), Same, but different: a common international approach to digital government, Government Digital Services, Cabinet Office, Available at: https://gds.blog.gov.uk/2015/07/29/same-butdifferent-a-common-international-approach-to-digital-government/; last accessed on 27/12/2018

Gefen, D., Karahanna, E., \& Straub, D. (2003). Trust and TAM in online shopping: an integrated model. MIS Quarterly, 27, 51-90.

Gliem, J. A. and Gliem, R. R. (2003). Calculating, interpreting, and reporting Cronbach's alpha reliability coefficient for Likert-type scales. Midwest Research-to-Practice Conference in Adult, Continuing, and Community Education. The Ohio State University, Columbus

Grace-Farfaglia, P., Dekkers, A., Sundararajan, B., Peters, L., \& Park, S. H. (2006). Multinational web uses and gratifications: Measuring the social impact of online community participation across national boundaries. Electronic Commerce Research, 6(1), 75-101.

Hair, J. F., Tatham, R. L., Anderson, R. E., \& Black, W. (2006). Multivariate data analysis. Upper Saddle River: Pearson Prentice Hall.

Hargittai, E. (2004). Internet access and use in context. New Media and Society, 6, 137-143.

Hargittai, E., \& Hinnant, A. (2008). Digital inequality differences in young adults' use of the internet. Communication Research, 35(5), $602-621$

Helbig, N., Ramón Gil-García, J., \& Ferro, E. (2009). Understanding the complexity of electronic government: Implications from the digital divide literature. Government Information Quarterly, 26(1), 89-97.

Helsper, E. (2008). Digital inclusion: An analysis of social disadvantage and the information society. London: Communities and Local Government

Helsper, E. J. (2012). A corresponding fields model of digital inclusion. Communication Theory, 22(4), 403-426.

Helsper, E. (2014). Harnessing ICT for social action, a digital volunteering programme. Digital inclusion in Europe: evaluating policy and practice Spain 2014. http://blogs.1se.ac.uk/ mediapolicyproject/2014/06/18/digital-inclusion-in-europeevaluating-policy-and-practice/. Accessed 25 March 2014

Helsper, E. J., \& Eynon, R. (2010). Digital natives: Where is the evidence? British Educational Research Journal, 36(3), 503-520.

Herzog, H. (1944). What do we really know about day-time serial listeners? In P. Lazarsfeld \& F. Stanton (Eds.), Radio research 19421943 (pp. 3-33). New York: Duel, Sloan and Pearce.

Hindman, D. B. (2000). The rural-urban digital divide. Journalism and Mass Communication Quarterly, 77, 549-560.

Hoffman, D., Novak, T. P., \& Peralta, M. (1999). Building consumer trust online. Communications of the ACM, 42(4), 80-85.

Horst, M., Kuttschreuter, M., \& Gutteling, J. M. (2007). Perceived usefulness, personal experiences, risk perception and trust as determinants of adoption of e-government services in the Netherlands. Computers in Human Behavior, 23(4), 1838-1852.

Hsieh, J. P.-A., Rai, A., \& Keil, M. (2008). Understanding digital inequality: Comparing continued use behavioral models of the socioeconomically advantaged and disadvantaged. MIS Quarterly, 32(1), 97-126.

Hsieh, J. P. A., Rai, A., \& Keil, M. (2011). Addressing digital inequality for the socioeconomically disadvantaged through government initiatives: Forms of capital that affect ICT utilization. Information Systems Research, 22(2), 233-253.

Hsu, M., \& Chiu, C. (2004). Predicting electronic service continuance with a decomposed theory of planned behaviour. Behaviour and Information Technology, 23(5), 359-373.

Hu, P. J., Chau, P. Y., Sheng, O. R. L., \& Tam, K. Y. (1999). Examining the technology acceptance model using physician acceptance of telemedicine technology. Journal of Management Information Systems, 16, 91-112.

Hung, S., Chang, C., \& Yu. (2006). Determinants of user acceptance of the e-Government services: The case of online tax filing and payment system. Government Information Quarterly, 23, 97-122.

Johnson, T. J., \& Kaye, B. K. (2003). Around the world wide web in 80 ways how motives for going online are linked to internet activities among politically interested internet users. Social Science Computer Review, 21(3), 304-325.

Kaplan, D. (2005). E-Inclusion: New challenges and policy recommendations. Brussels: e-Europe Advisory Group.

Karahanna, E., Straub, D., \& Chervany, N. (1999). Information technology adoption across time: A cross-sectional comparison of preadoption and post-adoption beliefs. MIS Quarterly, 23(2).

Karavasilis, I., Zafiropoulos, K., Vrana, V. (2010). Factors Affection the adoption of e-Governance by teachers in Greece. In Proceeding of 10th European Conference on E-Government, University of Limerick, Ireland, 17-18.

Ko, H., Cho, C., \& Roberts, M. S. (2005). Internet uses and gratifications: A structural equation model of interactive advertising. Journal of Advertising, 34(2), 57-70.

Korgaonkar, P. K., \& Wolin, L. D. (1999). A multivariate analysis of web usage. Journal of Advertising Research, 39, 53-68.

Kvasny, L., \& Keil, M. (2006). The challenges of redressing the digital divide: A tale of two cities. Information Systems Journal, 16(1), 23 53.

Lau, A. S., \& Kwok, V. W. (2007). How e-government strategies influence e-commerce adoption by SMEs. Electronic Government, an International Journal, 4(1), 20-42.

Lean, O. K., Zailani, S., Ramayah, T., \& Fernando, Y. (2009). Factors influencing intention to use e-government services among citizens in Malaysia. International Journal of Information Management, 29(6), 458-475.

Liao, S., Shao, Y. P., Wang, H., \& Chen, A. (1999). The adoption of virtual banking: an empirical study. International Journal of Information Management, 19(1), 63-74.

Loges, W. E., \& Jung, J.-Y. (2001). Exploring the digital divide: Internet connectdness and age. Communication Research, 28, 536-562.

Luo, M. M., Chea, S., \& Chen, J. (2011). Web-based information service adoption: A comparison of the motivational model and the uses and gratifications theory. Decision Support Systems, 51(1), 21-30.

Lynne, G. D., Franklin, C. C., Hodges, A., \& Rahmani, M. (1995). Conservation technology adoption decisions and the theory of planned behavior. Journal of Economic Psychology, 16(4), 581598.

Mahmood, M., Weerakkody, V., \& Chen, W. (2018). The influence of transformed government on citizen trust: Insights from Bahrain. Information Technology for Development. https://doi.org/10.1080/ 02681102.2018 .1451980 .

Mahmood, M., Weerakkody, V. and Cheng, W. (2019), The role of ICT in the transformation of government and citizen trust, International Review of Administrative Sciences, Forthcoming.

Mancinelli, E. (2008) 'E-inclusion in the information society', Information Society. In Theory to Political Practice: Course book. Budapest: Gondolt-Új Mandátum.

Mathieson, K. (1991). Predicting user intentions: comparing the technology acceptance model with the theory of planned behavior. Information Systems Research, 2(3), 173-191. 
Moon, J., \& Kim, Y. (2001). Extending the TAM for a world-wide-web context. Information and Management, 38(4), 217-230.

Mukherji, J., Mukherji, A., \& Nicovich, S. (1998). Understanding dependency and use of the internet: A uses and gratifications perspective. Boston: American Marketing Association.

Neuman, W.L. (2006). Social research methods: Qualitative and quantitative approaches. 6th Edition,University of Wisconsin, Whitewater, Pearson.

Oliver, R. L. (1980). A cognitive model of the antecedents and consequences of satisfaction decisions. Journal of Marketing Research, 460-469.

Papacharissi, Z., \& Rubin, A. M. (2000). Predictors of internet use. Journal of Broadcasting and Electronic Media, 44(2), 175-196.

Power, A., \& Wilson, W. J. (2000). Social exclusion and the future of cities, Centre for Analysis of social exclusion. London: London School of Economics.

Rice, R. E., \& Haythornthwaite, C. (2006). Perspectives on internet use: Access, involvement and interaction. In handbook of new media: Social shaping and social consequences of ICTs (pp. 92-113). SAGE Publications Inc.

Rogers, E. M. (1995). Diffusion of innovations (4th ed.). New York: Free Press.

Ruggiero, T. E. (2000). Uses and gratifications theory in the 21st century. Mass Communication and Society, 3(1), 3-37.

Saebø, Ø., Rose, J., \& Flak, L. S. (2008). The shape of eParticipation: Characterizing an emerging research area. Government Information Quarterly, 25(3), 400-428.

Saunders, M.N., Saunders, M., Lewis, P. and Thornhill, A. (2011). Research methods for business students. 5th edn. Pearson Education India.

Schaupp, L. C., Carter, L., \& McBride, M. E. (2010). E-file adoption: A study of US taxpayers' intentions. Computers in Human Behavior, 26(4), 636-644.

Sekaran, U. (2003). Research methods for business: A skill building approach (4th ed.). John Wiley and Sons, Inc: New York.

Seybert, H. (2011). 'Internet use in households and by individuals in 2011', Eurostat statistics in focus, vol. 66 .

Shelley, M. C., II, Thrane, L. E., \& Shulman, S. W. (2006). Lost in cyberspace: Barriers to bridging the digital divide in e-politics. International Journal of Internet and Enterprise Management, 4(3), 228-243.

Shih, Y., \& Fang, K. (2004). The use of a decomposed theory of planned behavior to study internet banking in Taiwan. Internet Research, 14(3), 213-223.

Stafford, T. and Stafford, M. (2001). 'Identifying motivations for the use of commercial web sites', Information Resources Management Journal, 14(1), pp.13 November 2017. Available from: http:// www.igi-global.com.v-ezproxy.brunel.ac.uk:2048/gateway/article/ 1194 ? $\mathrm{cb}=$ true.

Stafford, T. F., Stafford, M. R., \& Schkade, L. L. (2004). Determining uses and gratifications for the internet. Decision Sciences, 35(2), 259-288.

Swan, J. E., \& Trawick, I. F. (1981). Disconfirmation of expectations and satisfaction with a retail service. Journal of Retailing, 57(3), 49-67.

Tabachnick, B.G. and Fidell, L.S. (2001) 'Using multivariate statistics'.

Tam, C., Santos, D., \& Oliveira, T. (2018). Exploring the influential factors of continuance intention to use mobile Apps: Extending the expectation confirmation model. Information Systems Frontiers. https://doi.org/10.1007/s10796-018-9864-5.

Taylor, S., \& Todd, P. (1995). Assessing IT usage: The role of prior experience. MIS Quarterly, 19, 561-570.

Van Dijk, J. (2005). The deepening divide: Inequality in the information society. Thousand Oaks: Sage Publications, Inc.

Van Dijk, J. (2006). Digital divide research, achievements and shortcomings. POETICS, 34(4-5), 221-235.
Venkatesh, V., \& Morris, M. G. (2000). Why don't men ever stop to ask for directions? Gender, social influence, and their role in technology acceptance and usage behavior. MIS Quarterly., 24, 115.

Venkatesh, V., Morris, M. G., Davis, G. B., \& Davis, F. D. (2003). User acceptance of information technology: Toward a unified view. MIS Quarterly, 27, 425-478.

Venkatesh, V., Brown, S. A., \& Bala, H. (2013). Bridging the qualitativequantitative divide: Guidelines for conducting mixed methods research in information systems. MIS Quarterly, 37(1), 21-54.

Verdegem, P., \& Verhoest, P. (2008). The 'relative utility' approach for stimulating ICT acceptance: Profiling the non-user. European Journal of ePractice, 3, 36-46.

Waller, P., \& Weerakkody, V. (2016). Digital government: Overcoming the systemic failure of transformation. Working Paper 2. London: Brunel University Press.

Wang, Y. S., \& Shih, Y. W. (2008). Why do people use information kiosk? A validation of the unified theory of acceptance and use of technology. Government Information Quarterly, 26, 158-165.

Wasserman, I. M., \& Richmond-Abbott, M. (2005). Gender and the internet: Causes of variation in access, level, and scope of use'. Social Science Quarterly, 86(1), 252-270.

Weerakkody, V., El-Haddadeh, R., Sabol, T., Ghoneim, A., \& Dzupka, P. (2012). E-government implementation strategies in developed and transition economies: A comparative study. International Journal of Information Management, 32(1), 66-74.

Wei, L., \& Zhang, M. (2008). The impact of internet knowledge on college students' intention to continue to use the internet. Information Research, 13(3), 348.

Weiser, E. B. (2001). The functions of internet use and their social and psychological consequences. CyberPsychology and Behavior, 4(6), 723-743.

Wilson, K., Wallin, J. S., \& Reiser, C. (2003). Social stratification and the digital divide. Social Science Computer Review, 21(2), 133-143.

Wright, D., \& Wadhwa, K. (2010). Mainstreaming the e-excluded in Europe: Strategies, good practices and some ethical issues. Ethics and Information Technology, 12(2), 139-156.

Yu, B. A. N., Lorri, M. M., \& Fan, Z. (2018). E-inclusion or digital divide: An integrated model of digital inequality. Journal of Documentation, 74(3), 552-574.

Yulong, K., and Wenli, L. (2009). A study of the factors affecting the adoption of mobile instant messaging in China. In Eighth International Conference on Mobile Business, Dalian, Liaoning, China.

Zafiropoulos, K., Karavasilis, I., \& Vrana, V. (2012). Assessing the adoption of e-government services by teachers in Greece. Future Internet, 4(2), 528-544.

Zikmund, W. G. (2003). Business research methods (4th ed.). New York: The Dryden Press.

Publisher's Note Springer Nature remains neutral with regard to jurisdictional claims in published maps and institutional affiliations.

Ahlam Al-Muwil completed her $\mathrm{PhD}$ research in Management at Brunel University Business School in the UK in 2014. She received her MSc in Information Systems Management from University of Greenwich and BSc in Information Technology and Computing from the Open University in the UK. Her current research focuses on e-government, einclusion, and technology adoption. She is particularly interested in understanding the factors that influence e-Inclusion. Ahlam is a professional member of the British Computer Society and a member of British Academy of Management. 
Vishanth Weerakkody is the head of the School of Management at University of Bradford and a Professor of Information Systems Management and Governance at the Faculty of Management, Law and Social Sciences, University of Bradford. Prior to his academic career, Prof Weerakkody worked in a number of multinational organisations, including IBM UK. He has a successful track record of Research and Enterprise and has secured numerous research grants from funding bodies such as the European Commission (FP7 \& H2020), Economic and Social Research Council, Qatar Foundation and UK Local Government. His R\&D expertise spans several disciplines including, management decision making, ICT evaluation, public administration, social Innovation and process transformation. He has published over 250 peer reviewed articles and guest-edited special issues of leading journals and books on these themes.

Ramzi El-Haddadeh is an Associate Professor at the College of Business and Economics at Qatar University, Qatar. Prior to this, he was a Senior Lecturer at Brunel Business School, Brunel University London, UK. His research expertise lies in the context of organisational transformation and adoption for emerging innovative technologies and public sector services ICT enabled transformation. Dr El-Haddadeh has published his research in peer-reviewed articles in international Journals and conferences. In addition, he has several years of $R \& D$ experience in various domains including digital innovation and entrepreneurship, technology roadmaps, and developing evaluation indicators for ICT implementation research projects funded by several research agencies namely; FP7 ICT, ICTPSP, SSH and NPRPs-Qatar.
Yogesh K. Dwivedi is a Professor of Digital Marketing and Innovation, the University Dean of Academic Leadership (REF Research Environment) and Co-Director of Research at the School of Management, Swansea University, Wales, UK. Professor Dwivedi is also currently leading the International Journal of Information Management as its Editor-in-Chief. His research interests are at the interface of Information Systems (IS) and Marketing, focusing on issues related to consumer adoption and diffusion of emerging digital innovations, digital government, and digital marketing particularly in the context of emerging markets. Professor Dwivedi has published more than 300 articles in a range of leading academic journals and conferences that are widely cited (more than 10 thousand times as per Google Scholar). Professor Dwivedi is an Associate Editor of the European Journal of Marketing, Government Information Quarterly and International Journal of Electronic Government Research, and Senior Editor of the Journal of Electronic Commerce Research. More information about Professor Dwivedi can be found at: http://www.swansea.ac.uk/staff/som/academic-staff/y.k. dwivedi/. 